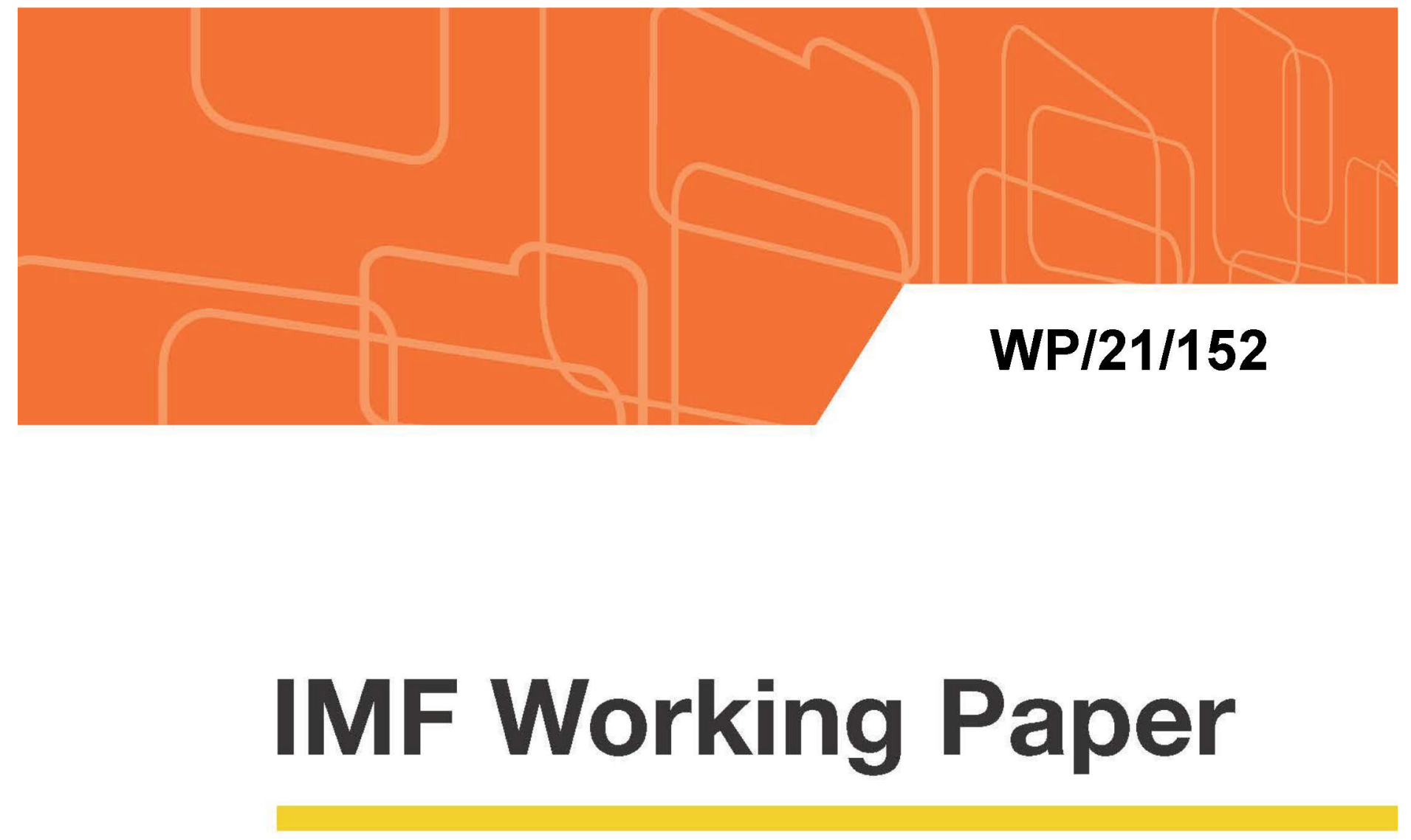

\title{
Restructuring and Insolvency in Europe: Policy Options in the Implementation of the EU Directive
}

by José Garrido, Chanda DeLong, Amira Rasekh, and Anjum Rosha

IMF Working Papers describe research in progress by the author(s) and are published to elicit comments and to encourage debate. The views expressed in IMF Working Papers are those of the author(s) and do not necessarily represent the views of the IMF, its Executive Board, or IMF management. 


\title{
IMF Working Paper
}

Legal Department

\section{Restructuring and Insolvency in Europe: Policy Options in the Implementation of the EU Directive}

\author{
Prepared by José Garrido, Chanda DeLong, Amira Rasekh, and Anjum Rosha
}

Authorized for distribution by Yan Liu

May 2021

IMF Working Papers describe research in progress by the author(s) and are published to elicit comments and to encourage debate. The views expressed in IMF Working Papers are those of the author(s) and do not necessarily represent the views of the IMF, its Executive Board, or IMF management.

\begin{abstract}
The Directive on Restructuring and Insolvency sets minimum standards for restructuring and certain insolvency matters, but its harmonization effect will be limited given multiple options for implementation, likely leading to divergent restructuring models in Europe. These options reveal different policy approaches to the regulation of restructuring and insolvency. The analysis in this paper aims to illustrate the breadth of the policy choices and their consequences for restructuring activity. States should carefully design restructuring procedures to avoid the negative economic effects of certain options that could undermine creditors' rights or result in unpredictable outcomes, particularly in cross-border cases.
\end{abstract}

JEL Classification Numbers: K22; G33

Keywords: restructuring, insolvency, European countries

Authors’ E-Mail Addresses: jgarrido@imf.org; cdelong@imf.org; arasekh@imf.org; arosha@imf.org 


\section{TABLE OF CONTENTS}

\section{INTRODUCTION}

II. THE MAIN BUILDING BLOCKS OF THE DIRECTIVE AND ITS POLICY OPTIONS

1. Early warning systems and access to information ___

2. Preventive restructuring ___ $Z$

i) Access _

ii) Debtor in possession _ $\underline{12}$

iii) Stay of creditor actions __ $\underline{13}$

a) Scope of the stay___

b) Duration of the stay_ 14

c) Lifting the stay __ 15

d) Effects on other legal remedies __

iv) Restructuring plans _ 16

a) Plan preparation — $\underline{17}$

b) Contents of the plan _

c) Voting by classes and required majorities__

d) Safeguards: Best interest of creditors' test and absolute priority ___

e) Treatment of shareholders and owners ___

f) Confirmation and appeal __ 24

g) Effects of the plan__ 25

v) New finance _ 25

3. Duties of directors __ 27

4. Discharge _

5. Institutional aspects _ _

i) Judicial or administrative authorities __ $\underline{31}$

ii) Insolvency practitioners __

iii) Electronic communications _

6. Data collection __

III. CONCLUSION___ $\underline{34}$

ANNEX 1. TABLE OF IMPLEMENTATION OPTIONS UNDER THE DIRECTIVE__ $\underline{36}$

REFERENCES

Box 1. European Models for Early Warning Systems

Figure 1: Options in Designing Access

Figure 2: Options in the Scope of the Stay

Figure 3: Options in the Duration of the Stay

Figure 4: Restrictions and Possibilities of Lifting the Stay

Figure 5: Options in Regulating Restructuring Plans

Figure 6: Options in Designing Cross-Class Cramdown

Figure 7: Safeguards in restructuring plans 


\section{INTRODUCTION}

The European Directive on restructuring and insolvency represents a milestone in the development of European insolvency law. On June 20, 2019, the European Union adopted the Directive 2019/1023, on restructuring and insolvency ("the Directive"). The text was the result of long and complex negotiations since the proposal was presented in 2016. In its final form, the Directive establishes some minimum standards for preventive debt restructuring mechanisms, debt discharge for entrepreneurs, and a limited subset of other insolvency issues.

The origins of the Directive can be traced to the EC Recommendation of 2014.

Recommendation 2014/135/EU (the "Recommendation") was the first European text to discuss substantive insolvency matters. The Recommendation addressed two main topics: (i) the need to provide a "second chance" to individual entrepreneurs across the EU, following a series of studies on the "entrepreneurship deficit" in Europe; and (ii) the idea of establishing restructuring frameworks in all member states, outside the scope of formal insolvency proceedings (i.e., informal and "hybrid" restructurings, which combine aspects of informal and formal procedures). ${ }^{1}$

The Recommendation gave way to a proposal for a Directive. After the Recommendation, the EC assessed the situation in member states and, due to the lack of adoption of satisfactory measures, presented a proposal for a binding text-a Directive - in November 2016. The text of the proposal was more ambitious than the Recommendation, including many more details in the area of restructuring, and also ancillary topics such as early warning systems, financial support for restructuring activities, and provisions on the institutional framework of insolvency systems. The proposal was the result of increased attention of the EC in insolvency and restructuring (Carpus Carcea et al., 2015, Bricongne et al., 2016), and was received as an opportunity to modernize European restructuring law (McCormack, 2017, Tollenaar, 2017), but it also attracted criticism (Eidenmüller, 2017).

The final text of the Directive ultimately reflects considerable compromise. The negotiation, both in the Council and in the European Parliament, resulted in numerous modifications to the legal text. Most of the changes introduced in the negotiation process watered down the harmonization effect of the Directive, mainly by introducing different implementation options for member states. The end result is "a puzzling variety of diverging options" (Rotaru, 2019).

This paper explores the different policy options that member states may take to implement the Directive into their national laws, and the trade-offs associated with different options. While the policy options are too numerous to cover in this introduction (see Annex I for a

\footnotetext{
${ }^{1}$ The European Commission recommended an approach based on informal or hybrid restructuring for several reasons: First, at the time, it was considered that venturing into harmonization of formal insolvency proceedings would be extremely difficult and politically not feasible. Second, the English scheme of arrangement, widely regarded as a hybrid restructuring tool, was being used by companies from other European countries, and this was creating a situation of competition with the insolvency systems in continental Europe. Third, the crisis in several European countries had shown that judicial systems did not have sufficient capacity to deal with high numbers of insolvency cases.
} 
complete list), the trade-offs involved in choosing any given policy option can generally be placed in two broad categories: (i) options that increase either creditor protection or debtor protection; and (ii) options that save costs and add flexibility, versus those that increase legal safeguards. Other choices are of a more technical nature: e.g., those that would be required under other areas of national law that have not been harmonized. In the area of restructuring, particularly significant choices include whether to introduce one or several restructuring procedures; how the Directive will affect judicial reorganization; the length and scope of the stay; the extent of interference with existing contractual relationships; the treatment of shareholders and secured creditors; the adoption of relative or absolute priority in the approval of restructuring plans; and new financing.

Given the impact of the COVID-19 pandemic, the urgency of improving restructuring and insolvency frameworks in the EU cannot be overstated. The Directive provides an opportunity to strengthen national systems at a time when most member states will experience widespread enterprise distress. Adequate implementation of restructuring procedures could alleviate the burden of the court system, offer more restructuring opportunities for viable enterprises (see Liu, Garrido and DeLong, 2020), and help minimize the impact of the crisis on the financial system.

The harmonizing effect of the Directive will be limited. Policy and technical choices of member states in the implementation of the Directive will likely result in different restructuring models (see Ehmke et al., 2019; JCOERE Consortium, 2019) which will result in systems that are located at different points of the spectrum within the broad categories outlined above. Differences among various restructuring models will persist, with consequences for creditor protection, debtor treatment and access to credit. If substantial differences emerge in the treatment of debtors and creditors, this will bring negative effects, especially in cross-border scenarios. Some countries may compete with each other in implementing the most effective restructuring framework, but this "race to the top" may also produce some dysfunctional effects, and in some cases, there may even be a "race to the bottom".

This paper is organized as follows: The main building blocks of the Directive are analyzed in Section II (i.e., early warning systems, restructuring procedures, director duties, discharge, institutional aspects, and data collection). Section III concludes. Annex I provides a complete list of options available to member states in the implementation of the Directive.

\section{THE MAIN BUILDING BLOCKS OF THE DIRECTIVE AND ITS POLICY OPTIONS}

\section{Early warning systems and access to information}

One of the innovations in the Directive is the introduction of early warning systems. Early warning mechanisms increase restructuring options and opportunities for the survival of the enterprise and are particularly necessary for SMEs. The Directive seeks to provide tools and 
incentives to allow early identification of debt distress, which aim to prevent the insolvency of enterprises by allowing remedial action at the earliest possible stage (for current European models, see Box 1).

\section{Box 1. European Models for Early Warning Systems}

In existing European practice, there are two competing models for early warning systems:

a) Early warning system as a self-assessment tool: Creating tools for entrepreneurs to assess their economic situation is especially useful for micro- and small enterprises, which may otherwise lack the analytical tools to assess their own performance and financial status. The self-assessment tool can be a simple software application on a public website: entrepreneurs only need to include basic data about their business, and the application will produce a preliminary diagnostic. A combination of financial and operational ratios can be used for this purpose. Of course, the quality of the diagnosis depends on the quantity and quality of the data supplied by the entrepreneur. This can be useful as a quick health check, but these self-assessment tools should be combined with support and advice provided by a public institution, or a commercial or professional association.

b) Early warning system as an intervention mechanism: This includes a series of steps to remedy the distress situation under external supervision. The system goes beyond mere detection of distress and includes also a cascade of interventions by different actors to ensure that issues are resolved without resorting to an insolvency proceeding. The following examples illustrate this approach:

- An observation that the going concern assumption is at risk will trigger the intervention of the auditor in an early warning system. An early warning system can be built on the auditor's obligation, expanding with a duty to communicate with the enterprise's management. If management is not responsive to the auditor's concerns, there may be subsequent communications with the board or even the shareholders' meeting. Eventually, the lack of adequate reaction of the enterprise organs can prompt the intervention of outside bodies, such as special mediation mechanisms, or even the courts.

- Other actors may also have the right to raise concerns with management regarding the risks affecting the enterprise: this can include minority shareholders or trade unions. Again, the lack of a proper reaction by management may trigger the intervention of other enterprise organs, or mediation bodies.

- The system may also foresee actions by creditors: these actions would be connected to the use of alternative dispute resolution.

- $\quad$ Public creditors can play a significant role in an early warning system: since distressed enterprises typically delay their tax and social security payments first, these creditors may perceive the difficulties of enterprises before other creditors. Unfortunately, these public creditors may not have the incentives to engage the distressed enterprises. Some systems may incentivize the public creditors to take action by the imposition of a duty to act, or by the loss of preferential treatment to their claims if they remain passive.

However, the content of the rules on early warning systems in the Directive is minimal. The Directive just requires countries to have an early warning system but neither defines this concept nor includes detailed prescriptions on the functioning and characteristics of such systems. The Directive only indicates a series of examples of elements of such systems, and member states need to implement one or several of the mechanisms included as examples in the Directive, namely:

- Alert mechanisms when the debtor has not made certain types of payments;

- Advisory services provided by public or private organizations; and 
- Incentives under national law for third parties with relevant information, such as accountants, tax and social security authorities, to flag to the debtor a negative development.

Implementing just one element of this list, however (the provision of advisory services, in particular) is unlikely to create an effective early warning system.

To create an effective early warning system, member states must choose a model (Box 1), define indicators, and establish the connection between the early warning system and insolvency/debt restructuring. With respect to the latter two elements, the following considerations apply:

a) Indicators for early warnings: Member states will have to choose which indicators will trigger an alarm or warning regarding the economic health of the enterprise. Concepts such as the risks to the continuity of the business may be used, although specific crisis indicators based on a combination of financial ratios, could have the added benefit of being calibrated for the special circumstances of economic sectors or types of enterprises. ${ }^{2}$ In addition, there are extremely simple, yet helpful, indicators, such as defaults, particularly of tax and social security obligations.

b) Connections with insolvency and debt restructuring: Another important policy choice refers to the connection of the early warning system with formal and informal mechanisms for debt resolution. Early warning systems tend to be valued for their confidentiality. Confidentiality is easily preserved when the early warning system is disconnected from formal insolvency: the early warning can simply consist of an alert message to the entrepreneur, with an offer to provide advisory services if required. But early warning can also be connected with other mechanisms, such as mediation or other forms of out-of-court restructuring of debt, still preserving confidentiality. A more interventionist system would establish the obligation to commence insolvency or preventive restructuring proceedings unless remedial action is taken. This would be consistent with the establishment of directors' duties to prevent insolvency (see Section 3 below).

\section{Preventive restructuring}

Preventive restructuring procedures represent the main building block of the Directive. In general, member states will have to incorporate or adapt existing procedures to allow enterprises to restructure their debt without full intervention of the courts, and before enterprises are insolvent (hence the term "pre-insolvency procedure"). This presents an opportunity to improve existing regimes (Vermeille and Rotaru, 2019). The overall objective is to maximize the use of hybrid restructuring, combining judicial actions with debtor-creditors negotiation (see Tollenaar,

\footnotetext{
${ }^{2}$ Examples of possible indicators include the following ratios: working capital / total assets (liquidity); retained earnings / total assets (profitability); earnings before interest and taxes / total assets (efficiency and viability); market value of equity / book value of total liabilities (only relevant for listed companies); sales / total assets (activity ratio); interest coverage ratio (ability of the enterprise to service the interest of its loans); and debt/earnings ratio (leverage).
} 
2019). The Directive provides a large range of policy and technical options to implement this broad policy objective, some of which have far-reaching consequences.

The focus on preventive restructuring was justified by an analysis by the EC. In its impact assessment accompanying the proposal for the Directive, the EC noted that there are European countries where it is not possible to restructure businesses before they are insolvent (EC, 2016). It also noted major differences among member states regarding specific aspects of restructuring. Since the number of cases with cross-border elements is quite significant in the $\mathrm{EU}^{3}$, the negative effects of deep divergences in restructuring mechanisms has an impact over credit intermediation (Banking Union) and raising capital across the EU (Capital Markets Union).

A fundamental option is whether to simply introduce a new restructuring procedure, introduce one or several restructuring procedures, or to implement a broad reform that would cover both restructuring procedures and formal reorganization. These options, with very different results, would be as follows:

- Implement the Directive by introducing a single pre-insolvency procedure (or adapting an existing one). This seems the option more aligned with the original thinking behind the Directive. The new restructuring procedure would stand side by side with the existing procedures under national insolvency law (typically, liquidation and reorganization). Preinsolvency procedures and formal reorganization procedures have separate spaces in an insolvency system (see Garrido, 2012). Although the final version of the Directive has blurred the lines between the two types of procedures, there is still an important difference in the degree of judicial intervention and of interference with creditors' and third parties' rights, which are considerably higher in the case of reorganization.

- Introduce a single pre-insolvency procedure and also targeted amendments to the existing reorganization procedure. This requires a broader and more complex reform of insolvency law, but it can ensure consistency between pre-insolvency and reorganization procedures.

- Introduce the Directive's rules throughout several restructuring procedures. This option was introduced to accommodate member states which have already a system that includes several restructuring procedures. Some member states have already implemented this approach: states can select different features of the Directive and offer several restructuring procedures (for instance, a restructuring procedure only for financial debts, or a restructuring procedure where the stay of creditor actions is confidential). In some cases, having different restructuring procedures is motivated by the possibility of using different recognition regimes, ${ }^{4}$ which affects the possibilities of cross-border use of these procedures. This option

\footnotetext{
${ }^{3}$ The EC estimated that one quarter of insolvency cases in the EU involved creditors and debtors in more than one-member state (EC, 2014).

${ }^{4}$ Restructuring procedures can be classified as insolvency procedures under the Insolvency Regulation (Regulation (EU) 2015/848), or as commercial proceedings under the Brussels Regulation (Regulation (EU) 1215/2012). See Skauradszun and Nijnens, 2019; and also, critically, Eidenmüller, 2019.
} 
increases the complexity of the system and can generate distortion in cross-border restructuring. Some countries may have restructuring procedures which are fairly accessible to foreign firms (i.e., with minimal connection requirements) and in this way will compete for restructuring cases. This can create a "forum-shopping" dynamic that undermines the goal of a harmonized regime.

- Merge the pre-insolvency procedure with the member state's existing reorganization procedures. This approach risks not achieving the Directive's objective of introducing restructuring options with reduced judicial intervention.

- Replace the member's reorganization procedure with the pre-insolvency procedure. This approach would eliminate reorganization from the insolvency system, leaving enterprises without the option of using reorganization, which provides a solution for enterprises that need more fundamental changes to their business structure, under closer judicial supervision.

\section{The control of restructuring procedures can be assigned to judicial or administrative} authorities. This is a crucial option that may be justified on grounds of efficiency (see Cahir and Quinn, 2020): in some member states, administrative authorities can perform better the functions of facilitating and overseeing restructuring negotiations. Naturally, there is a fundamental question of constitutionality which needs to be analyzed according to national law: the degree to which the administrative authorities can take decisions on private law issues, or how actions taken by administrative authorities in this area would be subject to the control of the courts.

\section{There are other general options that would broaden or narrow the scope of the Directive's application:}

- Financial institutions: The Directive allows member states to apply its rules to financial entities. This option does not seem particularly useful: even if the financial institutions are not of the kind subject to a special insolvency regime (such as banks), the design of preinsolvency procedures may not be adequate for them, especially for the emphasis on a debtor-in-possession approach, which may entail significant supervisory risks in the management of a distressed financial institution.

- Legal persons: Member states have the option to limit the application of the restructuring procedure to legal persons. This option narrows dramatically the scope of the Directive and would leave out micro- and small enterprises under sole or family ownership.

- Groups of companies: Member states have the option to extend the application of the restructuring procedure to groups of companies (see Zhang, 2019). Application of the preventive restructuring procedure to groups of companies requires the introduction of special rules for the coordination of procedures relating to the different companies belonging to the groups, including both national and foreign procedures. Member states should be mindful of the need for these rules when selecting this option. 
- SMEs: The Directive contemplates the possibility of introducing special rules for SMEs. These special rules are expressly mentioned in the Directive in some cases, and it would be possible to incorporate numerous rules in the Directive with different approaches for SMEs and for the rest of enterprises (see McCarthy, 2020). The Directive refers to "national definitions of SMEs", instead of the definitions used in European instruments. This will result in further dilution of the harmonizing effect of the Directive. States could follow the European definitions of micro, small and medium enterprises, and only deviate from such concepts where there is a sufficiently powerful reason to do so.

- Debts: Member states may limit the debts that would be subject to restructuring: existing and future claims of workers (existing or former); alimony; and tort claims. One of these exclusions (alimony claims) presupposes the application of the restructuring procedure to natural persons. Excluding the claims of workers is a policy option that is consistent with out-of-court restructuring practice (workers' claims are small and can complicate negotiations, so they are frequently left unaffected). Finally, excluding tort claims as a general category could be excessively broad. Member states interested in using this option could probably use it to exclude specific categories of tort claims (for instance, claims derived from death and bodily harm).

\section{i) Access}

Access to preventive restructuring procedures should be relatively easy to allow debtors to restructure their debts at an early stage but should be carefully balanced with preventing moral hazard. The Directive provides that the preventive restructuring procedure must only be available to debtors where there is a "likelihood of insolvency". This term is not defined and is left to the discretion of the national implementing law. As outlined in the Directive's recitals, the concept is designed to ensure that the process may not be commenced too early before an insolvency (in which case the company would be able to abuse the protection offered by the Directive to clear all its debts - in particular, the automatic stay), nor too late (rendering the restructuring process ineffective), for example when the company has already stopped making payments. The Directive only defines the moment when there is no longer a "likelihood of insolvency", i.e., the moment at which, under national law, the debtor is defined as being insolvent. As definitions of insolvency vary in member states, therefore, the moment at which businesses will be considered to have a "likelihood" of insolvency will also differ, diminishing the harmonization effect of the Directive across jurisdictions. Moreover, in theory, there is always a "likelihood" of insolvency, even if a business is currently solvent. Member states will have to carefully balance the desirability to give debtors in debt distress the ability to save their business, while preventing moral hazard. One way to do so may be to reference a time period prior to insolvency: e.g., there is "likelihood" of insolvency when there is a rational basis for the conclusion that the company may not be able to pay its debts within a certain period (e.g., within the next six months). 
The considerations at play in designing the "likelihood of insolvency" test are further complicated by the option to extend the scope of the framework to situations where the debtor faces non-financial difficulties. The recitals provide that such difficulties must give rise to a "real and serious" threat to the debtor's actual or future ability to pay its debt as they fall due. The time frame relevant for the determination of such a threat may extend to a period of several months or even longer to account for cases where the debtor is faced with non-financial difficulties threatening the status of its business as a going concern. This added flexibility under the Directive is important, in that it allows member states to provide early restructuring options for a business facing a significant non-financial shock such as (i) loss of a major contract; (ii) a large tort claim; or even (iii) a pandemic. However, given its wide scope, it increases the possibility of procedural abuse, and may necessitate early judicial intervention or other oversight measures to protect the interest of creditors.

Additional barriers to access, such as a history of fraud, past use of the procedure, and a test of "viability" may also be added to increase creditor protection. The Directive gives discretion to the member states whether to introduce these additional barriers; therefore, some jurisdictions may choose to make their procedures more restrictive (with an attendant reduction in moral hazard), while others may choose to make them more permissive (with the added moral hazard risk). For example, member states may provide that debtors that have been sentenced for serious breaches of accounting and bookkeeping obligations under national law may only access a preventive restructuring procedure after taking adequate corrective measures. This would give comfort to creditors that the information provided by the debtors as to their business is sufficiently credible to enable creditors to take a decision during restructuring negotiations. It also seems justified because the restructuring procedure leaves the debtor in possession of the business. Member states may also limit the number of times a debtor can access a preventive restructuring framework within a certain period, which again, is a step designed to prevent abuse, especially the repeated use of the stay of creditor actions. Member states may maintain or introduce a "viability test".

The option of including a "viability test", in particular, must be considered carefully. A full viability analysis would be too costly and complex as an entry requirement. If a "viability test" is maintained or introduced, it must have the purpose of excluding debtors which have no prospect for viability and should be carried out without serious detriment to the debtor's assets. While debtors could be required to pay the potential costs associated with the test, which should be verified by the judicial or administrative authority, a simple "viability test" (rather, an eligibility test) could likely be implemented with minimal cost (for instance, applicants could be asked to produce evidence of positive earnings in the past fiscal years). However, as with other barriers to entry outlined above, some member states may choose not to introduce any viability test and prioritize ease of access over creditor protection.

Finally, while the procedure must be available upon request by debtors, it leaves open many options for policy makers as to whether it may also be opened by creditors to implement a more "creditor friendly" approach (Figure 1). Member states could choose to 
allow only voluntary access by debtors. Alternatively, a more creditor-friendly approach would allow such procedures to be opened by creditors, even without debtor consent. As a middleground, and to preserve the voluntary nature of the procedures, however, member states could decide to also require the debtor's consent in such cases. Debtors' consent could be required only in the case of SMEs, which may require more protection than larger companies. States also have the option of providing access by workers' representatives, with similar options.

Figure 1: Options in Designing Access

\begin{tabular}{|l|l|l|}
\hline $\begin{array}{l}\text { Access by debtors } \\
\text { (mandatory) }\end{array}$ & Access by creditors & $\begin{array}{l}\text { Access by workers' } \\
\text { representatives }\end{array}$ \\
\cline { 2 - 3 } & $\begin{array}{l}\text { Access by creditors with } \\
\text { debtor consent }\end{array}$ & $\begin{array}{l}\text { Access by workers' } \\
\text { representatives with debtor } \\
\text { consent }\end{array}$ \\
\cline { 2 - 3 } & $\begin{array}{l}\text { Access by creditors with } \\
\text { consent of SME debtor }\end{array}$ & $\begin{array}{l}\text { Access by workers' } \\
\text { representatives with consent } \\
\text { of SME debtor }\end{array}$ \\
\hline
\end{tabular}

\section{ii) Debtor in possession}

Under the Directive, member states must ensure that debtors accessing the preventive restructuring procedure remain totally—or at least in part—in control of their assets and the day to day operation of the business. In pre-insolvency proceedings, it is important that the debtor generally remains in possession of the business - as debtors will be unlikely to use these proceedings if they will be removed from their business. Moreover, allowing debtor to remain in possession of the business allows for the smooth continuation of the business, potentially maximizing recovery value for creditors. However, particularly in the application of tools such as a general stay that encroach on creditors' rights, the ability of debtors to remain in control of the business must be balanced with protections against abuse.

The Directive provides that appointment of an insolvency practitioner is mandatory in certain circumstances, although its role in such cases is limited. Member states shall require the appointment of an insolvency practitioner at least where (i) a general stay of enforcement actions is granted by judicial or administrative authority and this authority decides that a practitioner is necessary to safeguard the interest of the parties; (ii) a judge or administrative authority needs to approve a restructuring plan with a "cross-class" cram down; or (iii) where it is requested by the debtor or by a majority of creditors (who should then bear the cost). However, the role of such an insolvency practitioner in the three above cases is limited to assisting the debtor and creditor in negotiating and drafting the plan.

Member states could decide to give the insolvency practitioner greater oversight over the debtor, increasing creditor protection while lowering ease of use, and blurring the line between restructuring and reorganization. In cases where an insolvency practitioner is required to be appointed to assist the debtor to negotiate and draft a plan (as outlined above), the 
member could expand the insolvency practitioner's role to supervise the actions of the debtor or take partial control of the daily operations of the business, for example by approving any transactions outside normal business operations. Member states may also decide on a case-bycase basis to appoint an insolvency practitioner, depending on the circumstances of the case or the debtor's needs, which may already exist under a member state's national law (e.g., in cases of fraud or mismanagement). Additional oversight by the insolvency practitioner would prioritize creditor protection, at the expense of low cost and ease of use of the procedure. In such cases of more heavy-handed oversight of preventive restructuring procedures, there may be little difference between preventive restructuring and more formal reorganization procedures.

\section{iii) Stay of creditor actions}

The stay of creditor actions must be carefully balanced to encourage good-faith debtors to apply for restructuring at an early stage of debt distress, while preventing moral hazard. A stay provides debtors who seek to restructure their debts with protection from acts by their creditors that may adversely impact the restructuring while a plan is being negotiated. The Directive provides that member states must ensure that debtors may benefit from a stay to support the negotiation of a restructuring plan. While a stay allows a restructuring to take place without the possibility that a creditor action may undermine a collective resolution of debt distress, it encroaches upon the contractual rights of creditors and must therefore be designed to sufficiently protect creditors' rights. This is particularly the case given that preventive restructuring regimes are used prior to insolvency — when there is only a likelihood of insolvency. In a situation where the debtor is only "likely" to be insolvent, pre-insolvency proceedings must take special care in designing a stay so that debtors do not abuse the proceedings merely to delay creditor action.

\section{a) Scope of the stay}

The Directive gives member states significant discretion over the scope of the stay, requiring member states to make key decisions regarding debtor versus creditor protection. For example, member states can choose whether the stay is general (applying to all creditors) or limited to affected creditors or only certain classes of creditors (e.g., financial creditors) (Figure 2). In that regard, unaffected creditors should be exempt, as they should be paid in full on their contractual terms and therefore there is no justification to have their enforcement rights against the debtor curtailed by a stay. Moreover, in informal restructurings, it is standard practice to have a standstill agreement among financial creditors, leaving other creditors unaffected. The Directive further provides that national laws may exclude certain claims or categories of claims from the stay in "well-defined" circumstances where such an 
exclusion is duly justified and where enforcement is not likely to jeopardize the restructuring of the business or where the stay could unfairly prejudice creditors. ${ }^{5}$

Figure 2: Options in the Scope of the Stay

\begin{tabular}{|l|l|l|}
\hline $\begin{array}{l}\text { General stay (including secured } \\
\text { and preferential creditors) }\end{array}$ & Limited stay & $\begin{array}{l}\text { No stay if unnecessary or } \\
\text { ineffective }\end{array}$ \\
\cline { 1 - 2 } & Only affected creditors \\
\cline { 2 - 3 } & $\begin{array}{l}\text { Only certain classes of creditors } \\
\text { (e.g. financial creditors }\end{array}$ & \\
\hline
\end{tabular}

The Directive also provides that member states may give the judge or administrative authority the right to refuse a stay where it is not necessary or would not fulfill the objective of supporting the negotiation on a restructuring plan. Grounds for such a refusal could be lack of a support by a majority of creditors, in which case no prospect of restructuring exists or that the debtor is actually insolvent, in which case the debtor should be subject to formal reorganization procedures or liquidated. Debtors could be presumed insolvent (with the ability to rebut such presumption) in the event of a substantial default vis-a-vis workers or tax or social security agencies, or where financial crime has been committed by the owner or management of a company that gives reason to believe that a majority of creditors will not support the start of negotiations on a restructuring plan.

A confidential stay can support some types of restructuring. In order to maximize chances of restructuring (e.g., by preserving ongoing credit relationships; suppliers' credits, etc.), the stay could be kept confidential so that only those creditors affected by the stay know it exists. This allows for the restructuring of debt with major financial creditors, in a mostly informal procedure with very limited court intervention (see Gassner and Wabl, 2019). This is an option that already exists in several member states, although lack of transparency has also raised concerns (Vermeille, 2018).

\section{b) Duration of the stay}

A stay should be sufficiently long to allow for meaningful restructuring negotiations, while not being excessive in duration. While the Directive provides that the initial period of the stay should be no more than four months, member states have significant discretion as to the length of the stay within that overall guidance (Figure 3). Given this optionality, it would be possible to have a system where the stay is one month, starting with commencement and no extensions (shortest system) versus a system where stay begins with the debtor's request, lasts for 4 months and can be extended until a total of 12 months. A limitation on the duration of a stay may

\footnotetext{
${ }^{5}$ An additional question may also arise as to how to treat claims that arise after a preventive restructuring has begun. Under normal insolvency procedures, such debts form part of the insolvency estate and are not subject to the stay on creditor actions. However, in a preventive procedure, there is no "estate." Extending the stay to these claims would reduce creditor rights, as well as the option of affecting interest payments, which is also contemplated as an option.
} 
incentivize the debtor and the creditors to reach agreement quickly on a restructuring plan. Complex restructurings may, however, require more time and therefore it may be advisable to allow for the possibility to request an extension of a stay, subject to certain conditions. Under the Directive, such conditions include progress on the restructuring plan, affected parties are not unfairly prejudiced, and insolvency proceedings have not been opened. In the interest of legal certainty, the total period of the stay (including extensions) should be limited. The Directive provides for a maximum period of twelve months.

Figure 3: Options in the Duration of the Stay (Options in green are more favorable to creditors; options in orange are more favorable to debtors)

\begin{tabular}{|l|l|l|}
\hline Initial Stay & Start & Extension \\
\hline Less than 4 months & With commencement of procedure & Not possible \\
\hline 4 months & With debtor's request & Until 12 months \\
\hline
\end{tabular}

c) Lifting the stay

Allowing creditors to request the lifting of the stay under certain conditions is essential to strike a fair balance between debtor and creditor rights. The Directive provides that a stay should be able to be lifted in several conditions (Figure 4). These include (i) when the stay no longer fulfils the objective of supporting restructuring negotiations (e.g., when a proportion of creditors who could block the adoption of a restructuring plan does not support the continuation of negotiations); (ii) the debtor or the insolvency practitioner so requests; (iii) if one or more creditors or classes of creditors would be unfairly prejudiced by the stay; or (iv) if the stay gives rise to the insolvency of the debtor.

Figure 4: Restrictions and Possibilities of Lifting the Stay

\begin{tabular}{|l|c|}
\hline Restrictions to lifting the stay & Possibilities of lifting the stay \\
\hline $\begin{array}{l}\text { Establish a period during } \\
\text { which stay cannot be lifted }\end{array}$ & $\begin{array}{l}\text { Lift stay in cases of unfair prejudice; insolvent } \\
\text { creditor; or stay does no longer support } \\
\text { negotiations }\end{array}$ \\
\cline { 2 - 2 } $\begin{array}{l}\text { Limit lifting the stay to } \\
\text { situations where creditors have } \\
\text { not had the opportunity of } \\
\text { being heard }\end{array}$ & - $\begin{array}{l}\text { Lift the stay for unfair prejudice for creditors } \\
\text { the stay }\end{array}$ \\
\hline
\end{tabular}

While the Directive does not provide specific rules relating to secured creditors, member states may wish to include them as further protection for creditors. In many insolvency laws where a stay also affects secured creditors, the interests of secured creditors are protected by specific rules that seek to provide 'adequate protection'. In that regard, member states should consider introducing protection for secured creditors. Such protection may, for example, include limiting the duration of the stay, allowing for the stay to be lifted at the request of the secured 
creditor, or adopting measures to ensure, where the value of the secured claim is more than or close to the value of the encumbered asset, that the value of the encumbered asset is protected against diminution. In contrast, the Directive includes options that would further undermine creditor rights, such as the options to extend the stay to guarantees or security interests granted by a third party. Implementing these options could have serious consequences for access to credit.

\section{d) Effects on other legal remedies}

The stay also extends to certain contracts, which makes it imperative for member states to establish safeguards for affected parties. The Directive obliges member states to ensure that, during the stay period, creditors to which the stay applies may not withhold performance or terminate, accelerate or in any other way modify essential executory contracts (e.g., lease and license agreements, long-term supply contracts, and franchise agreements). The Directive also provides that creditors may not enforce so called ipso facto clauses in their contracts (with the exception of financial contracts and financial collateral arrangements). These effects on contracts are more typical of reorganization procedures than of restructuring, where a standstill generally only applies to credit relationships. Given this wide scope, states should establish safeguards for the parties affected by this contractual stay, , such as the possibility of judicial revision of the status of the contract and the adoption of compensatory measures . The Directive also provides member states the option of extending the stay to contracts that are not essential. This option would make the restructuring procedure even more similar to reorganization, increase its complexity, and possibly generate litigation. At a minimum, safeguards such as those outlined above should be included.

\section{iv) Restructuring plans}

The key challenge in regulating the design of restructuring procedures under the Directive is how to maximize legal flexibility without the full judicial intervention attached to reorganization procedures. The rules in the Directive are complex for a restructuring procedure and are more similar to those in reorganization procedures. In that regard, member states will need to decide whether they want to maintain differences between plans in restructuring procedures and plans in formal reorganizations. Some of the options in the Directive increase the legal flexibility of plans, facilitating changes in the capital structure or even some restructuring of enterprise operations, while other options allow members states to modulate the complexity and costs of the procedure. Another set of options defines the balance of rights between creditors, on one side, and debtors and shareholders, on the other (see Figure 5).

Figure 5: Options in Regulating Restructuring Plans

\begin{tabular}{|l|l|l|}
\hline More functionality/ flexibility & Less cost and complexity & $\begin{array}{l}\text { More rights for debtors/special } \\
\text { groups of debtors }\end{array}$ \\
\hline More control/reliability & More cost and complexity & $\begin{array}{l}\text { More rights for creditors/special } \\
\text { groups of creditors }\end{array}$ \\
\hline
\end{tabular}




\section{a) Plan preparation}

The Directive presents member states with key tradeoffs regarding who should prepare the restructuring plan. While the debtor has the initiative to prepare the plan, the Directive allows the "establishing conditions" for creditors and insolvency practitioners to submit alternative restructuring plans. States interested in pursuing this option could establish a deadline for the presentation of the debtor's plan, after which creditors or the insolvency practitioner could submit a plan. Member states who introduce this option o will have to decide whether it is available only to creditors (and on which conditions: for instance, whether holding a certain percentage of liabilities is a requirement) or whether it is available to the insolvency practitioner. If the option adopted is to allow both creditors and insolvency practitioners to present an alternative plan, it is necessary to establish a hierarchy in the drafting of plans. Allowing creditors to present alternative plans has deep effects on the functioning of the procedure, increasing the flexibility of restructuring options and creditor protection. It also creates a different dynamic for debtors, who may lose control of the process and may be more reluctant to use the procedure for that reason.

\section{b) Contents of the plan}

Member states can supplement the minimum contents prescribed by the Directive, but this increases the cost and complexity of plans. The Directive follows the principle of flexibility of the plan, while establishing some minimum requirements. Member states can decide to establish more stringent and detailed disclosure requirements. However, the more mandatory elements the plan has, the more difficult it will be for the entrepreneur to prepare a plan without assistance, and the costs of the restructuring procedure will be higher.

The general principle is that the restructuring plan covers all debts previous to the restructuring. However, the Directive mentions that member states have the option of including in the procedure also the claims that arise after the submission of the application. This option creates complications by omitting a "cut-off" date for claims.

Although the restructuring procedure potentially affects all claims, there are options for the special treatment of public creditors, which need to be carefully assessed. The Directive allows member states to exclude a full or partial cancellation of the claims of a public institutional creditor with a privileged status. One of the reasons why this option may be appealing to some member states is the poor track record of public creditors in informal negotiations with debtors and other creditors. Since the Directive cannot modify the regime for the collection of tax and social security claims, this option allows some member states to introduce a restructuring procedure without creating a conflict with other legislation. However, using this option reduces the functionality of the restructuring mechanism, especially in cases where public debts are substantial.

Valuation is a fundamental element in restructuring plans, although it can be costly for small enterprises. Member states need to carefully consider their approach to the valuation 
requirement in restructuring plans. Valuation increases the costs of the restructuring procedure, but, at the same time, valuation represents essential information for a creditors' decision on the plan. Member states have the option of including in the plan an expert opinion regarding the value of the debtor's assets. If an expert assessment is missing, it is possible that the valuation included in the plan (in principle, prepared by the debtor) could underestimate the liquidation value to induce creditors to vote in favor of the plan. Therefore, this difference in the regulation of restructuring plans can translate into differences in creditor protection. A potential trade-off would be to exempt micro and small enterprises from the valuation requirement, while maintaining it for medium and large enterprises.

Viability analysis represents another key element of restructuring plans, but it can also have cost implications for small enterprises. The Directive does not mention the need to include a viability analysis as part of the plan. Member states have the option of including the validation of the debtor's statement indicating the feasibility of the plan, which seems equivalent to a viability analysis. The statement itself can be prepared by an external expert or an insolvency practitioner. There are multiple options: the requirement can include drafting or validation; and the preparation or the validation can be assigned either to external experts or to insolvency practitioners. In principle, an insolvency practitioner seems better placed to draft or validate a statement of reasons, but there can be exceptions both in the higher end of the spectrum (large companies) as well as in the lower end (micro- and small enterprises). In general, a viability analysis is a crucial element in ensuring an effective restructuring. For micro and small enterprises, however, it would be reasonable to exempt them from this requirement, which would make the procedure too costly, and use basic indicators of future profitability instead.

Implementing the option of allowing the sale of the business may deter debtors from using the restructuring procedure. The Directive allows the option of including the sale of the business in a restructuring plan. Whereas the Directive seems to be primarily designed for the financial restructuring of enterprises, the possibility of selling the business as a going concern allows the "rescue of the business" as opposed to the "rescue of the entity". Although this option enhances the flexibility of the procedure, there is also a certain inconsistency with the approach that informs the Directive, i.e., giving a chance to debtors to restructure their businesses. Selling the business as a going concern represents a potential threat for debtors who may refrain from using the restructuring procedure.

\section{c) Voting by classes and required majorities}

The Directive respects the basic principle that affected parties have a right to vote on the plan. Those who are not impacted negatively by the plan (i.e., creditors that will receive a full immediate payment) do not have the right to vote. The Directive also allows member states to exclude shareholders, subordinated creditors, and related parties with a conflict of interest. The option to allow equity holders to vote makes the procedure similar to the US Chapter 11 reorganization, where shareholders are classified as residual claimants and have the right to vote. 
However, in cases of clear balance-sheet insolvency, it would be justified to deny shareholders the right to vote. The other potential exclusions from the vote are related to existing exclusions in national insolvency regimes.

Member states can set flexible rules for the formation of classes, while avoiding possible manipulation by the debtor. The division of creditors in classes is the approach prescribed by the Directive. In order for the class voting mechanism to be effective, it is necessary that there is sufficient commonality of interests among the creditors included in the same class. It should be possible to form separate classes even when creditors belong to the same category (unsecured creditors can be divided in different classes - for instance, it is possible to have a class of suppliers and a class of customers). On the other hand, there is a risk that the debtor manipulates the class formation system to increase the chances of a favorable vote (which is akin to gerrymandering).

The control over the formation of classes should be balanced with the need to preserve the flexibility and speed of the restructuring procedure. The Directive allows different modalities of control over the formation of classes: Confirmation of classes can come before the vote takes place (ex ante confirmation) or can be included as part of the plan confirmation process (ex post confirmation). The possibility to validate the formation of classes before the vote increases the formality and duration of the process but also reduces the risks that the plan will be challenged. An alternative solution is to assign to an insolvency professional the responsibility of forming the classes, and demand that creditors disagreeing with the class formation raise this issue at the moment of the vote or before the vote.

The Directive allows member states to create a special class for workers' claims. The option of creating a separate class for workers is based on the fact that workers have other interests beyond being mere creditors, and also on the preferential ranking of many of their claims. The formation of a special class for workers reinforces the protection given to workers as creditors. Of course, member states can opt for the more radical measure of excluding workers from the effects of the procedure.

The Directive also allows member states to create a special class for small suppliers. The reference to small suppliers is unclear, as there could be small creditors who are worthy of special protection without being suppliers: a typical example would be consumers who have made advance payments for goods or services. Another point regarding this option is that member states can include this possibility in the law or enable the court or administrative authority overseeing the restructuring procedure to establish this special class. This second option could be more useful, since the need for this special class tends to be case-specific.

Splitting of the secured and unsecured portions of loans is optional, despite its necessity for the operation of the procedure. The separation of the secured and unsecured portions of a claim is implied in the legal framework of reorganization procedures, where creditors only have secured status to the extent that their claims are covered by the value of collateral. It is not 
possible to operate the basic safeguards of the Directive (especially, the best interest of creditors' test, also known as liquidation test), without a valuation of the collateral. Possibly, the option in the Directive was introduced with the intention of reducing the cost of the procedure, given that valuations can be expensive. However, valuation of collateral and splitting of claims are necessary elements for an efficient restructuring.

Member states can adopt rules to simplify the approval of restructuring plans of SMEs, while respecting the different position of creditors. The Directive allows member states to exempt SMEs from the formation of classes. This assumes that the class system may introduce unnecessary costs and complexity in small cases. As indicated before, using the "SME" category may not be entirely appropriate, since medium enterprises can present complex restructuring cases with multiple creditors, and this simplification option could be better targeted at micro and small enterprises. In the event that countries decide to let SME debtors eliminate classes, it would be necessary to introduce a decision-making mechanism that still respects the different position of creditors. The differentiation between secured and unsecured creditors should be contemplated even without classes: this can be done just by requiring that in computing the results of the general vote, there is a separate count for secured creditors and for unsecured creditors, so that a plan is adopted, for instance, if it receives the vote of a majority of unsecured creditors and a majority of secured creditors, even if all creditors vote at the same time in a single meeting. An alternative would be to require a majority in the general vote and a certain percentage of the vote among secured creditors, and maybe also among preferential creditors.

\section{In setting a quorum for the vote, member states need to consider the need to protect} debtors and creditors against random majorities. The Directive allows member states to set a participation quorum for the vote. This is a guarantee for creditors that there will be enough participation to take a meaningful vote on the restructuring plan. The Directive does not specify if the quorum that can be required is general or if it can refer to each class of creditors. If the quorum is demanding, the risk is that the lack of interest of creditors will render illusory the opportunity given to the debtor of restructuring the business. The lack of a quorum creates the opposite problem - the possibility of circumstantial majorities in favor of a restructuring plan, with minimal participation. Setting the specific threshold for a quorum needs to take into account the existing experience on the participation of creditors in insolvency proceedings.

\section{Special majority requirements reflect a trade-off between easiness of restructuring and} minority creditor protection. The vote organized within each class may be subject to special majority requirements. Member states are able to select the majority they desire for the approval of the restructuring plan, but the threshold cannot be higher than 75 percent. This is a critical option: the space between requiring an absolute majority (50 percent plus one vote) or a supermajority (typically, $2 / 3$ or 75 percent) is a major factor in the easiness or difficulty in restructuring debt. In some countries, the law sets different majorities depending on the contents of the plan (for instance, a lower majority for plans that only reschedule debts). Although it is not clear that this approach is entirely consistent with the Directive, it would be possible to consider this as an implicit option in implementing the text. Finally, the Directive recognizes the 
possibility of adding the requirement of a majority in number within the class. Majorities in number are designed to avoid the abuse of power by large creditors. In including a majority in number, countries need to assess the risk of majority abuse versus the added complication of the system and the reduction in the probabilities of adopting a plan.

\section{The multiple options in the design of cross-class cram-down reflects a similar trade-off} between ease of restructuring and minority creditor protection. Dividing creditors into classes may facilitate or hinder the adoption of a restructuring plan, depending on the circumstances. What facilitates adoption of plans in a class context is the existence of a crossclass cram-down rule, i.e., a rule that allows that the plan is adopted even if the plan did not gain majority support in one or several classes. The Directive allows multiple options in the design of such a rule. Practically, the only unavailable option would be a requirement that a plan is adopted by all classes (see Figure 6). Member states can require a positive vote on the plan by just one of the classes (as in US Chapter 11); require a higher fixed number of classes voting in favor (for instance, two or three classes); or require that a majority of classes votes in favor of the plan.

Figure 6: Options in Designing Cross-Class Cramdown

\begin{tabular}{|l|l|l|l|l|}
\hline $\begin{array}{l}\text { One class in } \\
\text { favor of plan }\end{array}$ & $\begin{array}{l}\text { Limited number } \\
\text { of classes (e.g., } \\
\text { two, or three } \\
\text { classes) in favor }\end{array}$ & $\begin{array}{l}\text { Majority of } \\
\text { classes }\end{array}$ & $\begin{array}{l}\text { Supermajority of } \\
\text { classes }\end{array}$ & $\begin{array}{l}\text { Unanimity of } \\
\text { classes (not } \\
\text { possible) }\end{array}$ \\
\hline
\end{tabular}

d) Safeguards: Best interest of creditors' test and absolute priority

\section{The system of safeguards of the Directive is inspired in modern reorganization}

frameworks. It incorporates not only class voting and cram-down, but also the key safeguards of reorganization: the best interest of creditors' test and the absolute priority rule (Figure 7).

Figure 7: Safeguards in restructuring plans

\begin{tabular}{|l|l|l|}
\hline Best interest of creditors' test & Absolute priority rule & Relative priority rule \\
\hline Protects individual creditors & Protects classes & Protects classes \\
\hline $\begin{array}{l}\text { Protects against receiving less } \\
\text { value than in liquidation }\end{array}$ & $\begin{array}{l}\text { Protects dissenting class by } \\
\text { denying any payment to } \\
\text { junior classes }\end{array}$ & $\begin{array}{l}\text { Only protects the dissenting class } \\
\text { by ensuring junior classes do not } \\
\text { receive more. }\end{array}$ \\
\hline Mandatory & $\begin{array}{l}\text { Optional (alternative to } \\
\text { relative priority); and } \\
\text { exceptions possible }\end{array}$ & $\begin{array}{l}\text { Optional (alternative to absolute } \\
\text { priority); no exceptions }\end{array}$ \\
\hline
\end{tabular}

The best interests of creditors' test, as a fundamental creditor protection, can be reinforced by choosing the criteria for determining the baseline liquidation value. The "best interests of creditors' test" protects individual creditors. This safeguard applies to any creditor, and states that no creditor should receive less, under the restructuring plan, than what they would have received in the liquidation of the debtor's estate. This safeguard is embedded in traditional 
insolvency law as a fundamental protection against the expropriation of creditor rights. In the Directive, the test is presented in a complex fashion: it is based on the hypothetical application of the ranking of claims either in the event of liquidation, whether piecemeal or sale as a going concern, or, in the event of the next best alternative scenario if the restructuring plan was not confirmed. This recognizes two problems: the first is that restructuring is not a reorganization, where the only alternative is a liquidation, so there may be other possible outcomes. Second, liquidation can consist of a sale of the business as a going concern or of a sale of assets. Countries need to consider carefully these options, because they affect the degree of creditor protection. The lowest baseline would be piecemeal liquidation. The value based on a going concern sale seems a more appropriate criterion, given the comparison with a restructured business which will continue operating. ${ }^{6}$

\section{Absolute priority is a traditional safeguard in reorganization that is also useful for the protection of classes in restructuring procedures. Absolute priority protects the interests of} classes of creditors. While the best of interests of creditors' test operates as individual protection for any creditor, the absolute priority rule is designed as a class protection measure. The absolute priority rule avoids that a distribution can be made to a lower class if a dissenting senior class is not paid in full. In practice, absolute priority is particularly relevant in the conflict between unsecured creditors and equity holders. According to absolute priority, it is not possible to impose any prejudice on unsecured creditors in order to allow equity holders to preserve an interest in the firm. Absolute priority fits better in the context of a formal insolvency proceeding than in preventive restructuring, but in any event, the underlying principle is valid for restructuring too: restructuring should not impose a transfer of value from a dissenting majority of creditors to the shareholders of the firm.

\section{The Directive gives the option to use relative priority, but this option presents risks.}

Relative priority implies that dissenting classes are treated as least as favorably as any other class of the same rank and more favorably than any junior class (see Stanghellini et al., 2018). Therefore, superior dissenting classes need to receive a better treatment than lower classes, but this does not imply that lower classes cannot receive any consideration. In the classic conflict between unsecured creditors and shareholders, this could mean that a dissenting majority of unsecured creditors could receive a 26 percent payment of their claims, whereas shareholders could keep 25 percent of their equity. Relative priority reduces the protection afforded to creditors and provides equity owners with a strategic advantage in the design of plans. This choice could create a sharp divide between countries opting for absolute priority and countries opting for relative priority, with important consequences for access to credit by firms and the potential distortion of cross-border credit activity (see de Weijs et al., 2019 and 2019b; Ballerini, 2020, Seymour and Schwarcz, 2021).

\footnotetext{
${ }^{6}$ The comparison of the payments under the restructuring plan with the "next best alternative scenario" seems to have been suggested by specific circumstances of a former member state, and it implies an added complexity in the application of the law, as it requires a totally different method to calculate the return to creditors.
} 
A better alternative is to incorporate absolute priority with targeted exceptions. Countries opting for absolute priority can introduce exceptions which are "necessary in order to achieve the aims of the restructuring plan and where the restructuring plan does not unfairly prejudice the rights or interests of any affected parties". The Directive provides examples such as when it is considered fair that equity holders keep certain interests under the plan despite a more senior class being obliged to accept a reduction of its claims, or essential suppliers covered by the provision on the stay of individual enforcement actions being paid before more senior classes of creditors. In general, countries could introduce limited and targeted exceptions to absolute priority and combine respect of the hierarchy of claims with some adaptability for special situations. One of the well-known exceptions to the absolute priority rule is "new value", based on the idea that owners or equity holders can retain an interest even if unsecured creditors do not approve the plan, in cases where they provide new financial resources or other value to the enterprise. In any event, this discussion belongs to the design of a formal reorganization more than that of a restructuring procedure. In a restructuring procedure there should be every attempt to reach a consensual solution among all parties, especially between shareholders and creditors.

\section{Member states can specify the concept of "payment in full" to exclude fully paid creditors} from the operation of the safeguards, but this should reflect the full satisfaction of claims within a reasonable time. The safeguards do not apply to creditors that receive a full payment: obviously, creditors who are fully paid cannot complain about junior creditors or equity holders receiving a distribution. But the concept of "payment in full", according to the Directive, can be defined by member states in different ways, "including in relation to the timing of the payment, as long as the principal of the claim and, in the case of secured creditors, the value of the collateral are protected". Some member states define payment in full as payment occurring within a maximum of three months of the confirmation of the plan, and the Directive seems to defer to member states in defining that concept differently. Payment of the principal in full, but within a long period of time (for instance one or two years) would be questionable. Member States can also decide on the choice of equivalent means for the satisfaction of the claim (for instance, payment in kind).

\section{e) Treatment of shareholders and owners}

Member states need to consider carefully whether to integrate shareholders as the last class of claimants or to maintain them separate from creditor classes. The Directive includes the option of creating a shareholder class, which may be subject to cram-down. The alternative option is to exclude shareholders altogether from the class voting mechanism, but in such a case member states need to ensure that shareholders cannot unreasonably prevent the adoption of the plan or create obstacles for its adoption or implementation. Integrating the shareholders in a class is consistent with the approach of some reorganization laws, which reduce shareholders to the status of "residual claimants". Under this approach, the consent of shareholders may be irrelevant (as when the shareholders are often "out of the money" because the company is balance-sheet insolvent) and their dissent may have very limited effects (a plan will be adopted even if one class -such as the shareholders' class- votes against it). If shareholders are not 
included among the voting classes, the question is whether there is some way for shareholders to negotiate the plan: this is where the Directive shows the contradictions of combining a reorganization model and a "consensual model", which is more typical of restructuring frameworks.

The requirement of the debtor's consent on the restructuring plan should not be used if shareholders are integrated as a class. If the debtor is an individual person, the debtor's consent requirement is clear and fits well with the nature of preventive restructuring as a consensual mechanism. If countries take the option of creating a shareholder class, they should also take the option that restricts the requirement for debtor's consent to SMEs possibly reducing the scope even further to micro and small enterprises, and especially to individual entrepreneurs. Any firm with substantial capital, where shareholders are included in a class, can be restructured according to the class voting mechanism, and superimposing the requirement of debtor's consent would be duplicative and distortionary. For the firms where debtors' consent is a required element, it is necessary to establish rules for the formation of consent. The Directive indicates that states may opt for attributing the representation of the debtor to "the legal person's management board" or to a "certain majority of shareholders or equity holders". This should be addressed consistently with national enterprise or company law.

\section{f) Confirmation and appeal}

The Directive indicates the cases in which confirmation of restructuring plans is necessary, and these cases seem sufficient to protect the interests at play. The Directive recognizes that a restructuring plan can be effective immediately without the need of formal confirmation. Confirmation by the court -or by an administrative authority-is required at least in the cases listed in the Directive, namely:

1. Plans that affect the rights of dissenting parties

2. Plans that provide for new financing

3. Plans that involve the loss of more of 25 percent of the workforce

This means that most plans will need to be confirmed, as many plans will fall under the first category, and possibly also under the second one. Member states can include additional cases for compulsory confirmation, although it is unclear whether adding more cases would be useful.

The Directive maintains a feasibility requirement for confirmation, but member states can provide more clarity on this requirement. The Directive expressly states that courts or administrative authorities should have the power to reject confirmation of plans where those plans are not feasible. Courts or administrative authorities may not always have the necessary resources to assess the feasibility of plans. Although the feasibility requirement is not optional, member states can decide that such an assessment need not be made ex officio. Member states can, in any event, define the conditions under which a plan would be considered not feasible. National laws could specify circumstances where plans cannot be implemented because of legal obstacles, or because the assumptions for the plan are obviously impossible. In this way, the 
concept of feasibility can be restricted so that it would not interfere with the confirmation process.

The Directive's framework seeks to reduce controversies over valuation. Valuation is fundamental in restructuring (Richter and Thery, 2020), but the experience in numerous countries is that reorganization proceedings can be saddled with litigation over valuation issues. Courts or administrative authorities will only take decisions on valuation when there is a challenge of the plan based on the violation of the best interests of creditors' test or of the absolute (or relative) priority rule. Litigation over valuation is particularly expensive, due to the need to engage experts, and is based on a hypothetical exercise that has been often described as a guess compounded by an estimate. Administrative and judicial authorities should encourage consensus to avoid litigation over valuation issues. The Directive allows the decision of the judicial or administrative authority on valuation to be based on a valuation submitted by an expert, a creditor, or a third party. States may align the regime for the decision with their own national frameworks applicable to similar disputes, which often rely on expert reports. The Directive also allows member states to establish special rules on valuation (for instance, reference to valuation standards), including rules on the burden of proof.

Member states should consider the rules for appeals against confirmation, balancing the protection of parties and the continuation of the plan. The rules on appeals leave numerous options for member states, and the Directive does not even include a general principle on the availability of appeals. Appeals should not suspend the execution of the plan, but this is also optional under the Directive.

\section{g) Effects of the plan}

The plan should generally bind all affected parties. The Directive mentions that the effects should be limited to "the affected parties that were involved in the adoption of the plan". This introduces two different concepts: "affected parties" and "involved parties". Affected parties are those whose rights are reduced by the effect of the provisions in the plan. The concept of "involved parties" seems to refer to parties that have been adequately notified and who have participated in the restructuring procedure. Member states have the option of determining the concept of "involved party", including rules for unknown creditors or creditors with future claims. For example, member states are able to decide how to deal with creditors that have been notified correctly but that did not participate in the procedure. Future creditors are generally excluded from the effects of restructuring.

\section{v) New finance}

The availability of financing is a key attribute of any successful restructuring plan. Financing may be needed initially by the debtor to continue its business operations while a restructuring negotiation is underway. The availability of this interim financing allows a debtor to cover its main operating costs (payments to crucial suppliers of goods and services, employees, rent, etc.) and sustain its operations until a plan is agreed upon. Financing may also 
be required later for the implementation of the restructuring plan (new financing). Without the willingness of creditors to forbear or provide financing, it may not be possible to rescue potentially viable businesses.

The risks of post-petition finance require that its treatment be clearly established under the legal framework so as to provide certainty and appropriate incentives for its grantors. Creditors will only be willing to inject financing in a distressed debtor if they have certainty that their credit will be sufficiently protected and prioritized relative to other claims. It is therefore important that the permissibility and ranking of post-petition financing be clearly established under the legal framework. Otherwise, it may be extremely difficult for distressed debtors to attract the financing they need for the survival of their businesses. The need for new finance has to be balanced against the increase of risks for pre-existing creditors (de Weijs and Baltjes, 2018).

As a general principle, the Directive requires member states to ensure that both new and interim financing are adequately protected. ${ }^{7}$ As minimum protections in any subsequent insolvency of the debtor, the Directive provides protection for new and interim financing from being declared void, voidable or unenforceable and for the grantors of such financing against civil, administrative or criminal liability; in both cases on the basis of the financing being detrimental to the general body of creditors.

\section{However, the number of options provided under the Directive will likely result in divergence in the scope and coverage of these protections across member states. For} instance, the Directive doesn't preclude excluding these protections based on other grounds that may be set forth by national laws of member states such as fraud, bad faith and conflict of interests in case of related party transactions. ${ }^{8}$ It also allows the limitation of these minimum protections to new and interim financing that meets certain requirements, for example, to cases where the restructuring plan has been confirmed by a judicial or administrative authority (in case of new financing) and to interim financing which has been subject to ex ante control. It also allows for the exclusion of interim financing granted after the debtor has become unable to pay its debts as they fall due from these protections.

\section{Unlike the original proposal, the Directive leaves the important issue of priority to}

member states' discretion. The Directive gives member states the discretion to provide grantors of new or interim financing with priority in subsequent insolvency procedures relative to other creditors that would otherwise have superior or equal claims. At the same time, it acknowledges that encouraging new lenders to take the risk of investing in a viable debtor in financial

\footnotetext{
${ }^{7}$ The Directive distinguishes between new and interim financing. New financing is considered as any new financial assistance provided by an existing or a new creditor in order to implement a restructuring plan and that is included in that restructuring plan. Interim financing includes any new financial assistance, provided by an existing or a new creditor, that includes, as a minimum, financial assistance during the stay of individual enforcement actions, and that is reasonable and immediately necessary for the debtor's business to continue operating, or to preserve or enhance the value of that business.

${ }^{8}$ Compared to the original proposal, the scope for excluding these protections under national laws has been widened (was initially limited it to transactions carried out fraudulently or in bad faith only).
} 
difficulties may require more incentives, such as the granting of priority in subsequent insolvency procedures at least over unsecured claims. This contrasts with the original proposal of the Directive which actually required member states, and rightly so, to rank new and interim financing at least senior to the claims of ordinary unsecured creditors.

States need to consider the trade-off between flexibility and safeguards. Necessitating court authorization is one way of managing the risks associated with post-petition finance, but this has to be weighed against other considerations such as the urgency of the financing and the value added by the courts' involvement. In the case of a reorganization procedure, court authorization or creditor consent may be required for the provision of post-petition finance, although it is desirable that the number of authorizations required be kept to a minimum given that finance tends to be required on a fairly urgent basis. A hierarchal approach to the authorization required may be taken, depending on the security or priority to be provided, level of finance and stance of creditors. Also, the debtor is usually better placed to assess whether financing is needed than the court. The foregoing would seem to call for an approach that ties authorizations to the priority to be granted, the level of financing in question and the stance of creditors. Restructuring, in any case, may need more flexibility than reorganization procedures, and there are less opportunities for judicial control. Alternative safeguards, such as those provided by the intervention of independent experts and administrative authorities, may be considered.

\section{Duties of directors}

The duties of directors in the period approaching insolvency have important relevance for preventive restructuring. These duties importantly aim at protecting the interests of different stakeholders from managerial decisions that may adversely impact the debtor's estate. At the same time, they may inadvertently limit directors' actions and discourage them from exercising business judgment or taking reasonable risks that could support the success of a restructuring so as to avoid any potential liability.

The Directive sets out steps that directors should take in order to minimize losses and avoid insolvency in cases where a company experiences financial difficulties. These include seeking professional advice (e.g. use of early warning tools - see Balp, 2019); protecting the assets of the company so as to maximize value and avoid loss of key assets; considering the structure and functions of the business to examine viability and reduce expenditure; not committing the company to the types of transaction that might be subject to avoidance unless there is an appropriate business justification; continuing to trade in circumstances where it is appropriate to do so to maximize going concern value; holding negotiations with creditors; and entering preventive restructuring procedures.

Where there is a likelihood of insolvency, the Directive requires directors to protect the legitimate interests of creditors. Specifically, in these cases, the Directive requires directors to have due regard, as a minimum, to the interest of creditors, other stakeholders and equity holders; the need to take steps to avoid insolvency; and the need to avoid deliberate or grossly 
negligent conduct that threatens the viability of the business. The original proposal envisaged the foregoing duties as hard obligations and required directors, in addition, to take immediate steps to minimize the loss for creditors, workers, shareholders and other stakeholders.

The Directive does not establish any hierarchy among the different stakeholders whose interests need to be given due regard. Instead, the Directive leaves this determination for member states.

To a large extent, the duties set forth in the Directive are a restatement of general company law and insolvency law principles. Their articulation in the Directive is meant to provide specific guidance to the judiciary in establishing directors' potential liability in insolvency cases. To this end, the Directive provides that member States could implement these duties by ensuring that judicial or administrative authorities, when assessing whether a director is held liable for breaches of duty of care, take these duties into account.

The assessment of compliance can be challenging, and specific implementation is likely to diverge across member states. To begin with, absent a definition in the Directive of what a "likelihood of insolvency" constitutes, even the trigger point for such duties is likely to vary significantly across member states. Further, the determination of what specific cases would be considered a violation of directors' duties will be left to member states (e.g. resignation at time of distress, contracting debt pre-insolvency, effect of successful plan negotiation on liability). It will also be for member states to determine what type of liability should be considered for directors failing to comply with their duties.

In determining liability, the important element should be the absence of any deliberate or grossly negligent actions. It is important that directors are not dissuaded from exercising reasonable business judgment and taking risks where warranted. The main consideration in the judgment on liability should be the extent to which a director acted in bad faith or in gross negligence, and not punishing bad business decisions as such.

The duties of directors present an area where restructuring and insolvency rules need to be well coordinated with company law. The provisions of the Directive as drafted only point to a broad policy direction, rather than providing detailed rules. Looking ahead, differences between regimes of member states in this area are likely to persist, and many jurisdictions may decide to leave their existing regimes unaltered in this area.

\section{Discharge}

The Directive highlights the importance of a second chance for entrepreneurs ${ }^{9}$, citing

\footnotetext{
${ }^{9}$ Entrepreneurs are understood to mean individuals exercising a trade, business, craft or profession. The Report of the European Commission Expert Group on a Second Chance for Entrepreneurs in 2011 found that fear of bankruptcy and its consequences acts as an effective deterrent to entrepreneurship and made the case that effective second chance policies should be pursued that ensure that business failure does not end up as a "life sentence" for the entrepreneur. The opportunity of a second chance while
} 


\section{evidence that entrepreneurs who have become insolvent have more chances of being}

successful the next time. The need for honest insolvent or over-indebted entrepreneurs to benefit from a full discharge after a reasonable period of time, thereby allowing them a second chance, is noted in the very first recital. Although the Directive does not include any binding rules on consumer over-indebtedness, entrepreneurs would not effectively benefit from a second chance if they had to go through separate business and consumer insolvency procedures, with different access conditions and discharge periods, to discharge their business debts and other debts incurred outside their business. Thus, the Directive advises countries that the guidance regarding discharge apply also to consumer debts.

\section{Several concerns with the current divergence in approaches to discharge across $\mathbf{E U}$} member states are noted in the Directive. The variation in the length of discharge periods, the conditions for granting a discharge and associated disqualification orders across EU states may cause entrepreneurs to relocate to other European jurisdictions in order to benefit from a second chance in a reasonable period of time, at considerable additional cost to both their creditors and the entrepreneurs themselves.

\section{Despite its stated goal of harmonization, the Directive does little more than offer an array} of options to EU member states (see Arias Varona et al., 2020). For example, the concept of 'insolvency' will continue to be defined by national law, and could take the form of "overindebtedness", resulting in divergent approaches. The insolvency procedure or procedures through which the goal of discharge may be achieved is not standardized but options are available allowing EU states to choose between a repayment plan procedure, liquidation of the debtor's assets, or a combination of both. EU states may require the debtor to request a discharge or it may be automatic at the end of the insolvency procedure. ${ }^{10}$ Where there is a procedure entailing a restructuring plan, the Directive does not require that a repayment plan be supported by a majority of creditors. Member states are therefore free to adopt rules regarding plan approval, the level of creditor consent required and how the courts would ratify such a plan.

\section{The seemingly definitive guidance on the three-year cap on the maximum period of the} discharge also warrants closer scrutiny. Although the discharge period is capped at a maximum of three years, states could opt for shorter discharge periods including possibly a variation of discharge periods between different procedures. Moreover, discharge at the end of a repayment plan and discharge at the end of a liquidation procedure could result in different timeframes depending on the steps and timelines of the procedure itself. In a procedure which includes a repayment plan, the three-year limit should commence from the date of the decision by a judicial or administrative authority to confirm the plan, or the start of the implementation of

protecting creditor interests was considered valuable for the entrepreneur, society, and the economy. Building on this, the 2014 Recommendation (see Introduction above) provided that honest entrepreneurs be fully discharged of their bankruptcy debts, without the need to re-apply to a court, after no more than 3 years from either the date of completion of liquidation of their assets or the date on which implementation of the repayment plan started.

${ }^{10}$ However, member states are required to ensure that debtors who have complied with their obligations are discharged without the need to apply to a judicial or administrative authority to open an additional procedure. 
the plan. In procedures that do not include a repayment plan, the discharge period should start, at the latest, from the date when a decision to open the procedure is taken by a judicial or administrative authority, ${ }^{11}$ or the date of the establishment of the insolvency estate. ${ }^{12}$ In the case of procedures which combine a realization of assets and a repayment plan, the discharge period should start, at the latest, from the date the repayment plan is confirmed by a court or starts being implemented, for example from the first instalment under the plan, but it could also start earlier, such as when a decision to open the procedure is taken. Thus, depending on the choices made by member states, and the time taken for various milestones in the process which could depend on factors such as the speed and efficiency of the courts, there could still be considerable variation in how quickly a debtor receives a discharge. Member states could also provide for a longer discharge period or restrict discharge in certain cases, e.g., repeat applications, abusive applications, cases where the cost of the procedure is not covered, and cases where a derogation is necessary to guarantee the balance between the rights of the debtor and the rights of one or more creditors. The Directive also permits longer discharge periods in certain cases, notably, if the primary residence of the entrepreneur is safeguarded from liquidation.

The scope of persons covered under the Directive could vary between member states. The Directive does not require member states to include consumer debts in the insolvency procedure although it is encouraged that at minimum a coordinated procedure for business and consumer debts be available. Member states may also require that the trade, business, craft or profession to which an insolvent entrepreneur's debts are related has ceased. Such a requirement would appear to preclude the use of a repayment plan by the entrepreneur, making liquidation the sole option.

The list of debts excluded from discharge is not standardized across member states. The Directive provides an indicative list of debts that are excluded from discharge, and member states may exclude these debts altogether, or restrict access to discharge of debt or lay down a longer discharge period for such debts.

\section{The Directive recognizes that derogations (rules denying or restricting access to discharge) may be necessary if the debtor is dishonest or has acted in bad faith, ${ }^{13}$ but lacks specific guidance and allows member states considerable latitude in framing these rules. The} Directive does not require that entrepreneurs benefit from a presumption of honesty and good faith, and member states may require entrepreneurs to prove compliance with their obligations in order to benefit from a discharge. Compliance could include a myriad of obligations that could vary between member states, including the possibility of introducing/maintaining derogations

\footnotetext{
11 The concept of 'opening of procedure' does not include preliminary measures, such as preservation measures or the appointment of a preliminary insolvency practitioner, unless such measures allow for the realisation of assets, including the disposal and the distribution of assets to creditors.

${ }^{12}$ The establishment of the insolvency estate should not necessarily entail a formal decision or confirmation by a judicial or administrative authority, where such decision is not required under national law, and could consist in the submission of the inventory of assets and liabilities

${ }^{13}$ Such rules may also be introduced where the entrepreneur has not complied with obligations under the repayment plan or other legal obligations safeguarding creditor interests, or with information or cooperation obligations; filed abusive applications; repeat applications for discharge; or where the cost of the procedure leading to the discharge of debt is not covered.
} 
where the entrepreneur has not complied with obligations to maximize returns to creditors or a general obligation to generate income or assets. Member states are required to provide a process by which it can be verified that the debtor has fulfilled the conditions for obtaining a discharge, but this process may be either judicial or administrative.

\section{Institutional aspects}

Efficiency and effectiveness of insolvency frameworks rely on implementing institutions. The main institutions are generally the judicial system (including courts or administrative authorities that perform adjudicative functions) and insolvency administrators.

\section{i) Judicial or administrative authorities}

In many European countries, insolvency matters are still handled by courts or judges that exercise general civil jurisdiction. Nonetheless, the complexity and time-sensitive nature of insolvency proceedings call for specialized independent judges with adequate training and expertise and particularly high ethical and professional standards. These qualifications are key to ensuring that court hearings can be held swiftly and that decisions are rendered quickly. The greater the discretion the law confers upon the court, the more important these qualifications are for the outcome and efficiency of the proceedings.

The Directive establishes rules with regard to the judiciary with the aim of establishing highly professional institutions across $\mathbf{E U}$ member states. In particular, the Directive mandates that judicial and administrative authorities dealing with procedures concerning preventive restructuring, insolvency and discharge of debt receive suitable training and have the necessary expertise for effectively performing their functions. It notes that there could be flexibility as to the timing of the training in that it could be on-the-job training, during the exercise of the duties or, prior to appointment to such duties. While the Directive notes that the creation of specialized courts and the appointment of specialized judges can help improve legal certainty and effectiveness of procedures, it clarifies that there is no requirement that members of a judicial authority have to deal exclusively with matters concerning restructuring, insolvency and discharge of debt.

\section{ii) Insolvency practitioners}

The Directive sets forth minimum standards for training, appointing, remunerating, and supervising insolvency representatives. Specifically:

- Eligibility and training: Member states are required to ensure that practitioners receive suitable training and have the necessary expertise for their responsibilities; and that the conditions for eligibility, as well as the process for the appointment, removal and resignation of practitioners are clear, transparent and fair.

- Appointment: The Directive specifies that in appointing a practitioner for a particular case, 
due consideration is given to the practitioner's experience and expertise, and to the specific features of the case; and that practitioners may be removed in case of objections by parties regarding conflict of interests.

- Supervision: The Directive requires that practitioners be supervised with a view to ensuring that their services are provided in an effective and competent way and that the practitioners act impartially and independently. Measures for the accountability of practitioners who have failed in their duties are also required to be established.

- Remuneration: Member states are required to ensure that the remuneration of practitioners is governed by rules that are consistent with the objective of an efficient resolution of procedures and that appropriate procedures are in place to resolve any disputes over remuneration.

- Code of Conduct: The Directive states that the development of and adherence to codes of conduct by practitioners may be encouraged by member states.

\section{iii) Electronic communications}

In addition to the institutions, the use of technology can significantly boost efficiency and the Directive seeks to promote the use of electronic means of communication. It establishes a minimum set of actions that may be performed using electronic means of communicationspecifically: filing of claims, restructuring or repayment plans, notifications to creditors, and challenges and appeals. However, member states may provide that notifications to creditors can only be performed electronically if the creditor concerned has previously consented to electronic communication.

\section{Data collection}

The collection of data is a fundamental step for the assessment and design of efficient and effective insolvency systems. Hard data is essential for evidence-based policymaking; relevant data provides the empirical foundation for the identification of issues and subsequently, formulation of changes to the law. The analysis of insolvency systems should hence be grounded on precise empirical data. Today, even in the most advanced economies, there is a need to increase the quality of insolvency-related information, in order to conduct a meaningful evaluation of insolvency systems. The Directive recognizes the importance of gathering data and requires member states to collect and aggregate certain data items on their insolvency systems.

The Directive identifies certain data categories that have to be collected and aggregated by member states on an annual basis with respect to each of the restructuring, insolvency, and discharge of debt procedures. These include (i) the number of procedures applied for, opened, pending, or closed; (ii) the average length of procedures from submission/opening to closures; (iii) the number of applications for restructuring procedures that were declared inadmissible, 
rejected or withdrawn; and (iii) the number of other procedures broken down by types of outcome. These are helpful indicators of the frequency of the use of the insolvency system and its effectiveness in responding to enterprise distress. Additionally, the Directive also requires the collection and aggregation of data on the number of debtors subject to restructuring/insolvency procedures which had a restructuring plan confirmed under a previous restructuring procedure within the three years prior to the submission of the application/opening of the procedure.

However, the collection of some additional data categories is left to the discretion of member states. These include the average cost of each procedure; the average recovery rates for secured, unsecured and other types of creditors; the number of entrepreneurs launching a new business after a discharge and the number of job losses linked to restructuring and insolvency procedures.

Compared to the initial proposal, the data categories required to be collected under the Directive have been limited and the option for collection and aggregation through sample techniques have also been introduced. Importantly, the collection of data on the average cost of each procedure, the recovery rates for secured and unsecured creditors, as well as the number of procedures with zero or not more than two percent total recovery rate in respect of each type of procedure, was originally envisaged to be required under the Directive. Also, when collecting mandatory or voluntary data categories, the Directive now gives member states the option to do so through a sample technique that is representative in terms of size and diversity.

The approach of voluntary data categories and sampling techniques could lead to a significant variation in the amount of data collected and aggregated by member states. This would complicate data comparability and completeness across the membership making it difficult to draw evidence-based policy lessons from the different experiences of states with the Directive.

Member states are hence encouraged to collect and aggregate all the data categories under the Directive, but also to go beyond these data items and be ambitious in their data collection efforts. Specifically, the core indicators of time, cost and recovery rate are highly relevant measures of the efficiency of an insolvency system. Additional data items could also be very useful; for instance, the number of insolvency cases closed because of lack of assets. Beyond such indicators aimed at the measurement of the effectiveness and efficiency of the system, it is possible to collect a wide range of information to understand the interaction between the legal system and economic and social reality. Through the appropriate designation of data collection points, such data can be extracted along different stages of insolvency procedures.

In considering the costs of the data collection system, member states are well advised to weigh such costs against those of not having one in place. Capacity and budgetary constraints should not become insurmountable barriers to the implementation of data collection systems and member states should create/bolster their data collection systems building on existing infrastructure. There are already multiple data sources which partially cover insolvency data, and 
an effort of rationalization could simplify the existing mechanisms and produce information of better quality. By contrast, ignoring how the insolvency system works in practice, and where its main challenges lie, can result in severe consequences for the economy, as the issues in the insolvency system remain unidentified and financial creditors do not properly adjust for the real duration and recovery rates in insolvency. In addition, lack of data may render legal reforms ineffective (see Garrido et al., 2019).

\section{CONCLUSION}

The Directive on Restructuring and Insolvency is a welcome first step in the convergence of EU insolvency frameworks. The Directive addresses an important and wide range of topics: early warnings, restructuring procedures, institutional aspects of insolvency systems, and data collection. The Directive has benefitted from the experience of European systems in the development of restructuring legislation and mechanisms to prevent the insolvency of enterprises.

Adequate implementation of the Directive can bring much-needed improvements to national systems, especially in the context of the current crisis. The Directive introduces a procedure that allows for the comprehensive restructuring of enterprises with reduced court intervention. The debtor-in-possession regime and the stay of creditor actions are strong incentives for enterprises to approach this procedure before their financial situation is desperate. Cross-class cram-down improves the possibilities of reaching a restructuring agreement. These flexible restructuring procedures can increase the possibilities of recovery for distressed enterprises in the EU, particularly in countries that may experience a wave of insolvencies as a result of the current crisis, since they reduce the need for extensive judicial intervention. The introduction of early warning systems, the establishment of a fresh start policy for individual entrepreneurs, and the improvement of the institutional framework and the data collection systems can strengthen European insolvency regimes.

However, the complex set of options for implementation present member states key tradeoffs with respect to (i) creditor versus debtor protection and (ii) flexibility and cost savings versus increased legal safeguards. Certain options available to member states, such as long stays of creditor actions without sufficient safeguards, interference with contractual relationships, not splitting secured claims into their secured and unsecured portions, adopting relative priority in the approval of restructuring plans, or not providing sufficient protection to new financing, could have negative effects for credit protection and should be carefully evaluated. Many options, while allowing for maximum flexibility to design restructuring plans, may have the unwanted effect of blurring the line between restructuring procedures and reorganization.

Moreover, differences in European restructuring and insolvency regimes will persist after implementation of the Directive, despite its goal of harmonization. The Directive shows that harmonization of insolvency laws, particularly important in the context of the Banking Union 
and the Capital Markets Union (see Bhatia et al., 2019), is a complex challenge, only achievable in the long term (Bergthaler and Garrido, 2019). Member states will make use of the different options included in the Directive, which reflect different approaches to the regulation of restructuring and insolvency and reveal preferences in terms of flexibility, controls, costs, and protection of debtors and creditors. Member states should pay special attention to the cumulative effects of options and to the consistency of their choices as they implement the Directive. In any event, the mosaic of restructuring regimes and the persistence of differences in other areas included in the Directive will warrant further analysis after member states reform their national regimes. Substantial differences in the treatment of debtors and creditors can generate negative effects, particularly in cross-border cases. Diverging implementation of the Directive can result in competition among member states, but it remains to be seen whether such competition will be positive (a "race to the top") or negative (a "race to the bottom"). 
ANNEX 1. TABLE OF IMPLEMENTATION OPTIONS UNDER THE DIRECTIVE

\begin{tabular}{|c|c|c|}
\hline Issue & Article/ recital & Effect of option \\
\hline \multicolumn{3}{|l|}{ General options } \\
\hline $\begin{array}{l}\text { Application to financial } \\
\text { entities }\end{array}$ & art. 1.3 & broaden scope \\
\hline $\begin{array}{l}\text { Application of discharge } \\
\text { procedures to natural } \\
\text { persons who are not } \\
\text { entrepreneurs }\end{array}$ & art. 1.4; rec. 21 & Broaden scope \\
\hline $\begin{array}{l}\text { Application of preventive } \\
\text { restructuring only to legal } \\
\text { persons }\end{array}$ & art. 1.4 & Restrict scope \\
\hline $\begin{array}{l}\text { Application of preventive } \\
\text { restructuring to groups of } \\
\text { companies }\end{array}$ & rec. 24 & Broaden scope \\
\hline $\begin{array}{l}\text { Exclusion of certain debts } \\
\text { from preventive } \\
\text { restructuring (workers' } \\
\text { claims, alimony, tort claims) }\end{array}$ & art. 1.5 & Restrict scope \\
\hline $\begin{array}{l}\text { Introduce one or several } \\
\text { restructuring procedures }\end{array}$ & art. 4 & Structural option \\
\hline $\begin{array}{l}\text { Assign competences over } \\
\text { restructuring procedures to } \\
\text { courts or to an } \\
\text { administrative authority }\end{array}$ & & Institutional \\
\hline $\begin{array}{l}\text { Use a definition of SME and } \\
\text { apply different rules in } \\
\text { several cases, as allowed by } \\
\text { the Directive }\end{array}$ & rec.18 & $\begin{array}{l}\text { Simplification, reduction of } \\
\text { harmonization }\end{array}$ \\
\hline \multicolumn{3}{|l|}{ Early warning } \\
\hline $\begin{array}{l}\text { Use one or more tools } \\
\text { among those included as } \\
\text { examples in the Directive }\end{array}$ & art. 3.1 & Flexible content \\
\hline $\begin{array}{l}\text { Use of IT for notifications } \\
\text { and communications }\end{array}$ & Art. 3.1 & Reduce cost; increase effectiveness \\
\hline
\end{tabular}




\begin{tabular}{|c|c|c|}
\hline Issue & Article/ recital & Effect of option \\
\hline $\begin{array}{l}\text { Development by member } \\
\text { states or by the private } \\
\text { sector }\end{array}$ & rec. 22 & Institutional \\
\hline $\begin{array}{l}\text { Provide support to } \\
\text { employees' representatives } \\
\text { to assess the economic } \\
\text { situation of the debtor }\end{array}$ & Art. 3.5 & Workers' rights \\
\hline \multicolumn{3}{|l|}{$\begin{array}{l}\text { Access to the restructuring } \\
\text { procedure }\end{array}$} \\
\hline $\begin{array}{l}\text { Provide that debtors with } \\
\text { serious accounting violations } \\
\text { may only access } \\
\text { restructuring if corrective } \\
\text { measures are taken }\end{array}$ & art. 4 ; rec. 27 & Barriers to entry \\
\hline $\begin{array}{l}\text { Restrict access to debtors } \\
\text { with deficient financial } \\
\text { information }\end{array}$ & rec. 27 & Barriers to entry \\
\hline $\begin{array}{l}\text { Use a viability filter (i.e., } \\
\text { clearly non-viable } \\
\text { enterprises will not have } \\
\text { access to restructuring) }\end{array}$ & art. 4 & Barriers to entry \\
\hline $\begin{array}{l}\text { If there is a viability filter, } \\
\text { impose the costs of proving } \\
\text { compliance with the test on } \\
\text { the debtor }\end{array}$ & rec.26 & Costs \\
\hline $\begin{array}{l}\text { Allow preventive } \\
\text { restructuring also for cases } \\
\text { of non-financial difficulties }\end{array}$ & rec. 28 & Expand access \\
\hline $\begin{array}{l}\text { Limit the frequency of } \\
\text { access (i.e., number of } \\
\text { consecutive applications, } \\
\text { period between one } \\
\text { application and another) }\end{array}$ & art. 4 & Barriers to entry \\
\hline $\begin{array}{l}\text { Limit the involvement of a } \\
\text { judicial or administrative } \\
\text { authority to where it is } \\
\text { necessary }\end{array}$ & art. 4.6 & Streamline the process \\
\hline
\end{tabular}




\begin{tabular}{|c|c|c|}
\hline Issue & Article/ recital & Effect of option \\
\hline $\begin{array}{l}\text { Allowing the application by } \\
\text { creditors or workers with } \\
\text { the debtor's agreement }\end{array}$ & art. 4 & Balance of rights debtor/creditors \\
\hline $\begin{array}{l}\text { Restrict the requirement of } \\
\text { the debtor's agreement to } \\
\text { SMEs }\end{array}$ & rec. 29 & $\begin{array}{l}\text { Differentiated treatment for SME } \\
\text { debtors }\end{array}$ \\
\hline \multicolumn{3}{|l|}{$\begin{array}{l}\text { Debtor in possession; } \\
\text { control of the debtor }\end{array}$} \\
\hline $\begin{array}{l}\text { Add more cases to the } \\
\text { mandatory ones in the } \\
\text { Directive for the } \\
\text { appointment of an } \\
\text { insolvency practitioner to } \\
\text { control the debtor. }\end{array}$ & art. $5.2 ; 5.3$; rec. 30 & Increase creditor rights \\
\hline \multicolumn{3}{|l|}{ Stay of creditors' actions } \\
\hline $\begin{array}{l}\text { Add the possibility of } \\
\text { refusing the stay where it is } \\
\text { not necessary or where it } \\
\text { would not achieve its } \\
\text { objective. If yes, on which } \\
\text { grounds? (lack of support by } \\
\text { required majorities of } \\
\text { creditors; or the debtor is } \\
\text { unable to pay its debts as } \\
\text { they fall due) }\end{array}$ & art. 6.1 & Increase creditor rights \\
\hline $\begin{array}{l}\text { Establish (on a rebuttable } \\
\text { basis) presumptions for the } \\
\text { presence of grounds for the } \\
\text { refusal of the stay }\end{array}$ & rec. 33 & Increase creditor rights \\
\hline $\begin{array}{l}\text { General stay (applicable to } \\
\text { all creditors) or limited } \\
\text { (applicable to one or more } \\
\text { creditors, informed of the } \\
\text { stay or the plan) }\end{array}$ & art. 6.3 & Decrease or increase creditor rights \\
\hline $\begin{array}{l}\text { Allow the stay to apply to } \\
\text { the benefit of a third-party } \\
\text { security provider (e.g. } \\
\text { guarantors, collateral givers) } \\
\text { as well. }\end{array}$ & art. 1.4 , rec. 32 & Decrease creditor rights \\
\hline
\end{tabular}




\begin{tabular}{|c|c|c|}
\hline Issue & Article/ recital & Effect of option \\
\hline $\begin{array}{l}\text { Exclude certain claims from } \\
\text { the stay }\end{array}$ & art. 6.4 , rec. 34 & $\begin{array}{l}\text { Increase rights of certain creditors; } \\
\text { improve functionality }\end{array}$ \\
\hline $\begin{array}{l}\text { Apply the stay to workers } \\
\text { claims when these are } \\
\text { covered by guarantees }\end{array}$ & art. 6.5 , rec. 61 & $\begin{array}{l}\text { Improve functionality; no prejudice to } \\
\text { workers }\end{array}$ \\
\hline $\begin{array}{l}\text { Allow the stay to affect the } \\
\text { interest due on claims }\end{array}$ & rec. 25 & Decrease creditor rights \\
\hline $\begin{array}{l}\text { Reduce the maximum period } \\
\text { of } 4 \text { months for the initial } \\
\text { stay }\end{array}$ & art. 6.6 & Increase creditor rights \\
\hline $\begin{array}{l}\text { Extend the stay, with } \\
\text { conditions, up to a } \\
\text { maximum of } 12 \text { months. In } \\
\text { that case, define who is } \\
\text { entitled to request the } \\
\text { extension. }\end{array}$ & art. 6.7 & $\begin{array}{l}\text { Potentially decrease creditor rights. } \\
\text { Increased functionality. }\end{array}$ \\
\hline $\begin{array}{l}\text { Provide for an indefinite stay } \\
\text { where the debtor becomes } \\
\text { insolvent under national law }\end{array}$ & rec. 35 & $\begin{array}{l}\text { Connection with national insolvency } \\
\text { law }\end{array}$ \\
\hline $\begin{array}{l}\text { Include a short interim stay } \\
\text { for the period where the } \\
\text { decision on access is } \\
\text { pending }\end{array}$ & rec. 35 & $\begin{array}{l}\text { Decrease creditor rights } \\
\text { Increase functionality }\end{array}$ \\
\hline $\begin{array}{l}\text { Lift the stay when creditors } \\
\text { are unfairly prejudiced, } \\
\text { when a creditor becomes } \\
\text { insolvent because of the } \\
\text { stay, or when the stay no } \\
\text { longer fulfils the objective of } \\
\text { supporting the negotiations }\end{array}$ & art. 6.9; rec. 36 & Increase creditor rights \\
\hline $\begin{array}{l}\text { Lifting the stay for unfair } \\
\text { prejudice for one or more } \\
\text { creditors or for all creditors } \\
\text { (and establish who is } \\
\text { entitled to request the lifting } \\
\text { of the stay) }\end{array}$ & rec. 37 & Increase creditor rights \\
\hline $\begin{array}{l}\text { Limit the cases of lifting the } \\
\text { stay to situations where } \\
\text { creditors have not had the } \\
\text { opportunity to be heard }\end{array}$ & art. 6.9 & Decrease creditor rights \\
\hline
\end{tabular}




\begin{tabular}{|c|c|c|}
\hline Issue & Article/ recital & Effect of option \\
\hline $\begin{array}{l}\text { Provide a minimum period } \\
\text { for which the stay cannot be } \\
\text { lifted. }\end{array}$ & art. 6.9 & Decrease creditor rights \\
\hline $\begin{array}{l}\text { Allow the commencement } \\
\text { of insolvency procedures } \\
\text { during the stay, provided } \\
\text { that the courts/authorities } \\
\text { can suspend the insolvency } \\
\text { case when if it is not in the } \\
\text { general interest of creditors }\end{array}$ & art. 7.3 & Increase creditor rights \\
\hline $\begin{array}{l}\text { Allow the request to } \\
\text { commence an insolvency } \\
\text { case by the public } \\
\text { prosecutor }\end{array}$ & rec. 38 & Protection of public interest \\
\hline $\begin{array}{l}\text { Suspend the obligation of } \\
\text { the debtor to pay the claims } \\
\text { that came into existence } \\
\text { before commencement of } \\
\text { the restructuring procedure }\end{array}$ & rec. 39 & $\begin{array}{l}\text { Preservation of relative positions of } \\
\text { creditors }\end{array}$ \\
\hline $\begin{array}{l}\text { Introduce safeguards for } \\
\text { creditors affected by the } \\
\text { effects of the stay on } \\
\text { essential contracts }\end{array}$ & art. 7.4 & Increase creditor rights \\
\hline $\begin{array}{l}\text { Extend the stay to other } \\
\text { executory contracts that are } \\
\text { not essential }\end{array}$ & art. 7.4 & Decrease third-party rights \\
\hline $\begin{array}{l}\text { Provide that the stay does } \\
\text { not apply to netting and } \\
\text { close out of non-financial } \\
\text { contract }\end{array}$ & art. 7.6; rec. 94 & Increase rights of certain creditors \\
\hline $\begin{array}{l}\text { Provide that the suspension } \\
\text { of the debtor's obligation to } \\
\text { file an insolvency procedure } \\
\text { due to the stay may be } \\
\text { derogated at the request of } \\
\text { public authorities acting in } \\
\text { the general interest }\end{array}$ & rec. 38 & Protection of public interest \\
\hline Restructuring plan & & \\
\hline
\end{tabular}




\begin{tabular}{|c|c|c|}
\hline Issue & Article/ recital & Effect of option \\
\hline $\begin{array}{l}\text { Indicate that restructuring } \\
\text { also includes the sale of the } \\
\text { business as a going concern }\end{array}$ & art. 2.1.1 & $\begin{array}{l}\text { Increase functionality; reduce } \\
\text { incentives for debtor }\end{array}$ \\
\hline $\begin{array}{l}\text { Require additional } \\
\text { explanations in the } \\
\text { restructuring plan }\end{array}$ & rec. 42 & $\begin{array}{l}\text { Increase creditor rights } \\
\text { Increase costs }\end{array}$ \\
\hline $\begin{array}{l}\text { Require an expert opinion } \\
\text { regarding the value of assets }\end{array}$ & rec. 42 & $\begin{array}{l}\text { Increase creditor rights } \\
\text { Increase costs }\end{array}$ \\
\hline $\begin{array}{l}\text { Establish that the statement } \\
\text { of reasons of the } \\
\text { restructuring plan needs to } \\
\text { be made or validated by an } \\
\text { external expert or by an } \\
\text { Insolvency Practitioner (IP) }\end{array}$ & art. 8.1.h & $\begin{array}{l}\text { Increase creditor rights } \\
\text { Increase costs }\end{array}$ \\
\hline $\begin{array}{l}\text { Allow the possibility that } \\
\text { creditors and IPs submit } \\
\text { alternative plans }\end{array}$ & art. 9.1 & $\begin{array}{l}\text { Increase creditor rights; increase } \\
\text { functionality }\end{array}$ \\
\hline $\begin{array}{l}\text { Include claims that fall due } \\
\text { or that come into existence } \\
\text { after the submission of an } \\
\text { application to open a } \\
\text { preventive restructuring } \\
\text { procedure in the } \\
\text { restructuring }\end{array}$ & rec. 25 & $\begin{array}{l}\text { Increase functionality; increase } \\
\text { complexity }\end{array}$ \\
\hline $\begin{array}{l}\text { Exclude from the right to } \\
\text { vote any of the following } \\
\text { categories: equity holders, } \\
\text { subordinated creditors, or } \\
\text { related parties with a } \\
\text { conflict of interests }\end{array}$ & art. 9.3 & $\begin{array}{l}\text { Changes balance of power in the } \\
\text { procedure }\end{array}$ \\
\hline $\begin{array}{l}\text { Permit equity-holders to } \\
\text { have a right to vote on the } \\
\text { restructuring plan }\end{array}$ & rec. 57 & $\begin{array}{l}\text { Changes balance of power in the } \\
\text { procedure }\end{array}$ \\
\hline $\begin{array}{l}\text { Use national law criteria to } \\
\text { determine who are } \\
\text { "affected parties" }\end{array}$ & art. 2. 1.2 & $\begin{array}{l}\text { Unclear whether there is any other } \\
\text { option. }\end{array}$ \\
\hline $\begin{array}{l}\text { Introduce a participation } \\
\text { threshold for the vote }\end{array}$ & rec. 47 & $\begin{array}{l}\text { Decreased functionality; increased } \\
\text { safeguards }\end{array}$ \\
\hline
\end{tabular}




\begin{tabular}{|c|c|c|}
\hline Issue & Article/ recital & Effect of option \\
\hline $\begin{array}{l}\text { Decide not to impose a full } \\
\text { or partial cancellation of the } \\
\text { claims of a public } \\
\text { institutional creditor with a } \\
\text { privileged status }\end{array}$ & rec. 52 & $\begin{array}{l}\text { Increased protection for public } \\
\text { creditors }\end{array}$ \\
\hline $\begin{array}{l}\text { Create a separate class for } \\
\text { workers }\end{array}$ & art. 9.4; rec. 44 and 62 & Increased protection for workers \\
\hline $\begin{array}{l}\text { Create a separate class for } \\
\text { small suppliers }\end{array}$ & rec. 44 & $\begin{array}{l}\text { Increased protection for a special class } \\
\text { of creditors }\end{array}$ \\
\hline $\begin{array}{l}\text { Eliminate the obligation to } \\
\text { create classes for SMEs }\end{array}$ & art. 9.4 & Simplification \\
\hline $\begin{array}{l}\text { Establish rules for contested } \\
\text { claims in the allocation of } \\
\text { voting rights }\end{array}$ & rec. 46 & $\begin{array}{l}\text { Increased functionality; increased } \\
\text { complexity. }\end{array}$ \\
\hline $\begin{array}{l}\text { Establish the confirmation of } \\
\text { the formation of classes at } \\
\text { an earlier stage, before the } \\
\text { vote }\end{array}$ & art. 9.5; rec. 46 & $\begin{array}{l}\text { Increased complexity and cost; higher } \\
\text { reliability. }\end{array}$ \\
\hline $\begin{array}{l}\text { Divide secured claims into } \\
\text { secured and unsecured parts }\end{array}$ & rec. 44 & $\begin{array}{l}\text { Increased functionality; better } \\
\text { balancing of rights }\end{array}$ \\
\hline $\begin{array}{l}\text { Use a majority in number of } \\
\text { creditors in addition to the } \\
\text { required majority in amount } \\
\text { of claims }\end{array}$ & art. 9.6; rec. 47 & $\begin{array}{l}\text { Increased minority protection; reduced } \\
\text { functionality }\end{array}$ \\
\hline $\begin{array}{l}\text { Establish specific notification } \\
\text { requirements to creditors } \\
\text { regarding class composition }\end{array}$ & rec. 51 & $\begin{array}{l}\text { Increased cost and complexity; higher } \\
\text { reliability }\end{array}$ \\
\hline $\begin{array}{l}\text { Establish the time frame for } \\
\text { the notification to creditors }\end{array}$ & rec. 51 & $\begin{array}{l}\text { If there are specific requirements, the } \\
\text { option becomes necessary }\end{array}$ \\
\hline $\begin{array}{l}\text { Establish provisions for the } \\
\text { treatment of unknown } \\
\text { claims }\end{array}$ & rec. 51 & Increased functionality \\
\hline $\begin{array}{l}\text { Provide that non-affected } \\
\text { parties are informed about } \\
\text { the restructuring plan }\end{array}$ & Rec. 51 & $\begin{array}{l}\text { Increased reliability. Increased } \\
\text { complexity. }\end{array}$ \\
\hline $\begin{array}{l}\text { Set the majority for the } \\
\text { approval of a restructuring }\end{array}$ & art. 9.6 & $\begin{array}{l}\text { Selection of the threshold is a trade-off } \\
\text { between functionality and minority } \\
\text { protection }\end{array}$ \\
\hline
\end{tabular}




\begin{tabular}{|c|c|c|}
\hline Issue & Article/ recital & Effect of option \\
\hline \multicolumn{3}{|l|}{$\begin{array}{l}\text { agreement (at or below the } \\
\text { maximum of } 75 \text { percent) }\end{array}$} \\
\hline $\begin{array}{l}\text { Replace the voting } \\
\text { requirement with an } \\
\text { agreement }\end{array}$ & art. 9.7; rec. 43 & Increased functionality \\
\hline $\begin{array}{l}\text { Add more cases where } \\
\text { confirmation of the plan is } \\
\text { required, beyond those } \\
\text { established in the Directive }\end{array}$ & art. 10.1 ; rec. 48 & Increased rigidity \\
\hline $\begin{array}{l}\text { Add more conditions to } \\
\text { confirmation (beyond those } \\
\text { required) }\end{array}$ & art. 10.2; rec. 50 & Increased rigidity \\
\hline $\begin{array}{l}\text { Design the cram-down } \\
\text { requiring a majority of } \\
\text { classes voting in favor of the } \\
\text { plan; one class; or several } \\
\text { classes. }\end{array}$ & art. 11.1 & $\begin{array}{l}\text { Selection of the number of classes in } \\
\text { favor of the plan is a trade-off between } \\
\text { functionality and minority protection }\end{array}$ \\
\hline $\begin{array}{l}\text { Require that the assessment } \\
\text { of viability is done by the } \\
\text { judicial or administrative } \\
\text { authority ex officio }\end{array}$ & rec. 50 & $\begin{array}{l}\text { Increased cost and complexity. } \\
\text { Increased reliability. }\end{array}$ \\
\hline $\begin{array}{l}\text { Limit the requirement of the } \\
\text { debtor's agreement with the } \\
\text { plan to SMES }\end{array}$ & art. 11.1 & Special treatment for SMEs \\
\hline $\begin{array}{l}\text { In case of requiring the } \\
\text { consent of the debtor for } \\
\text { adoption or confirmation of } \\
\text { the plan, establish that the } \\
\text { debtor is represented by the } \\
\text { legal person's management } \\
\text { board or by a certain } \\
\text { majority of shareholders or } \\
\text { equity holders }\end{array}$ & rec. 53 & Increased clarity. \\
\hline $\begin{array}{l}\text { Introduce absolute priority } \\
\text { or relative priority, with the } \\
\text { possibility of including } \\
\text { exceptions to absolute } \\
\text { priority. }\end{array}$ & $\begin{array}{l}\text { art. } 11.1 ; 11.2 \text {; rec. } 55 \text {, } \\
\text { rec. } 56\end{array}$ & Increase or decrease creditor rights \\
\hline $\begin{array}{l}\text { Establish conditions to } \\
\text { determine "payment in full" }\end{array}$ & rec. 56 & Possibility to decrease creditor rights \\
\hline
\end{tabular}




\begin{tabular}{|c|c|c|}
\hline Issue & Article/ recital & Effect of option \\
\hline \multicolumn{3}{|l|}{$\begin{array}{l}\text { (timing and alternative } \\
\text { payments) }\end{array}$} \\
\hline $\begin{array}{l}\text { Define the elements of the } \\
\text { best interests of creditors } \\
\text { test, comparing the } \\
\text { outcome in the plan with a) } \\
\text { a piecemeal liquidation; b) a } \\
\text { going concern liquidation; or } \\
\text { c) "the next best alternative } \\
\text { scenario" }\end{array}$ & art. 2 ; rec. 52 & $\begin{array}{l}\text { Going concern liquidation increases } \\
\text { creditor rights, while piecemeal } \\
\text { liquidation reduces them. "Next best } \\
\text { alternative scenario" lacks clarity. }\end{array}$ \\
\hline $\begin{array}{l}\text { If public creditors have } \\
\text { priorities, provide that the } \\
\text { plan cannot impose a full or } \\
\text { partial cancellation of their } \\
\text { claims }\end{array}$ & rec. 52 & Increase protection of public creditors \\
\hline $\begin{array}{l}\text { Introduce measures to avoid } \\
\text { that shareholders block the } \\
\text { approval or implementation } \\
\text { of the restructuring plan }\end{array}$ & art. 12.3 & Increase functionality \\
\hline $\begin{array}{l}\text { Allow a valuation challenge } \\
\text { to be lodged in the context } \\
\text { of an appeal against a } \\
\text { decision on confirmation }\end{array}$ & art. 14.3 & Increase creditor rights \\
\hline $\begin{array}{l}\text { Allow the decision of the } \\
\text { judicial or administrative } \\
\text { authority on valuation to be } \\
\text { based on a valuation } \\
\text { submitted by an expert, a } \\
\text { creditor, or a third party }\end{array}$ & rec. 63 & Increase reliability; increase costs \\
\hline $\begin{array}{l}\text { Establish special rules for } \\
\text { valuation, including rules on } \\
\text { burden of proof }\end{array}$ & rec. 63 & Increase or decrease creditor rights \\
\hline $\begin{array}{l}\text { Determine the concept of } \\
\text { "involved creditors" }\end{array}$ & rec. 64 & $\begin{array}{l}\text { More than an option, it is a necessity } \\
\text { under the law. Different definitions will } \\
\text { imply different levels of protection for } \\
\text { creditors }\end{array}$ \\
\hline $\begin{array}{l}\text { Establish rules for the } \\
\text { treatment of creditors who } \\
\text { were notified correctly but } \\
\text { did not participate in the } \\
\text { process }\end{array}$ & rec. 64 & Completeness of the regime \\
\hline
\end{tabular}




\begin{tabular}{|c|c|c|}
\hline Issue & Article/ recital & Effect of option \\
\hline $\begin{array}{l}\text { Allow the appeal of a } \\
\text { decision on the confirmation } \\
\text { of a restructuring plan } \\
\text { issued by a judicial } \\
\text { authority. Establish the } \\
\text { grounds for appeal. }\end{array}$ & rec. 65 & $\begin{array}{l}\text { Increase or decrease creditor rights. } \\
\text { Increase or decrease functionality }\end{array}$ \\
\hline $\begin{array}{l}\text { Allow the modification of } \\
\text { the plan in case an appeal is } \\
\text { upheld }\end{array}$ & rec. 65 & $\begin{array}{l}\text { Increased functionality and flexibility. } \\
\text { Potential reduction of creditor rights. }\end{array}$ \\
\hline $\begin{array}{l}\text { Suspend the execution of } \\
\text { the restructuring plan when } \\
\text { there is an appeal }\end{array}$ & art. 15.3 & $\begin{array}{l}\text { Increased functionality; reduced rights } \\
\text { of parties. }\end{array}$ \\
\hline $\begin{array}{l}\text { Grant monetary } \\
\text { compensation to the } \\
\text { appealing party in some } \\
\text { cases }\end{array}$ & art. 15.4; rec. 65 & Increased functionality \\
\hline \multicolumn{3}{|l|}{ New finance } \\
\hline $\begin{array}{l}\text { Limit the protection of } \\
\text { interim finance to cases } \\
\text { where plans are adopted or } \\
\text { confirmed }\end{array}$ & rec. 68 & Increased security; reduced flexibility \\
\hline $\begin{array}{l}\text { Introduce ex ante controls } \\
\text { for interim financing }\end{array}$ & rec. 68 & Increased security; reduced flexibility \\
\hline $\begin{array}{l}\text { Provide priority to new } \\
\text { finance }\end{array}$ & art. 17.4 & Increased functionality \\
\hline $\begin{array}{l}\text { Limit the protection of new } \\
\text { finance or restructuring } \\
\text { transactions to the cases } \\
\text { where financial assistance } \\
\text { has been subject to } \\
\text { confirmation or ex ante } \\
\text { control }\end{array}$ & art. 18.2 & Increased security; reduced flexibility \\
\hline $\begin{array}{l}\text { Establish a point in time } \\
\text { prior to the opening of the } \\
\text { procedure from which } \\
\text { certain fees and costs } \\
\text { benefit from protection } \\
\text { against avoidance. For other } \\
\text { payments and workers' } \\
\text { wages, establish that point }\end{array}$ & rec. 69 & Increased security for finance providers \\
\hline
\end{tabular}




\begin{tabular}{|c|c|c|}
\hline Issue & Article/ recital & Effect of option \\
\hline \multicolumn{3}{|l|}{$\begin{array}{l}\text { at the opening of the } \\
\text { procedure }\end{array}$} \\
\hline $\begin{array}{l}\text { Exclude protection of new } \\
\text { finance granted after the } \\
\text { debtor is insolvent }\end{array}$ & art. 18.3 & Increased security; reduced flexibility \\
\hline $\begin{array}{l}\text { Include more transactions } \\
\text { under the protective rules }\end{array}$ & art. 18.4 & Increased flexibility; reduced security \\
\hline \multicolumn{3}{|l|}{ Directors' duties } \\
\hline $\begin{array}{l}\text { Use the rules included in the } \\
\text { Directive to establish } \\
\text { directors' liability }\end{array}$ & rec. 71 & $\begin{array}{l}\text { Completeness; or connection with } \\
\text { national law }\end{array}$ \\
\hline $\begin{array}{l}\text { Establish a hierarchy among } \\
\text { the different parties whose } \\
\text { interests need to be taken } \\
\text { into account by directors }\end{array}$ & rec. 71 & $\begin{array}{l}\text { Increased specificity. Increased } \\
\text { complexity. }\end{array}$ \\
\hline \multicolumn{3}{|l|}{ Discharge of debts } \\
\hline $\begin{array}{l}\text { Define insolvency as over- } \\
\text { indebtedness }\end{array}$ & rec. 73 & Connection with national law \\
\hline $\begin{array}{l}\text { Establish one procedure or } \\
\text { several procedures for } \\
\text { discharge }\end{array}$ & art. 20.1 & connection with national law \\
\hline $\begin{array}{l}\text { Require the debtor to } \\
\text { request discharge }\end{array}$ & rec. 73 & $\begin{array}{l}\text { Increased complexity; less favorable for } \\
\text { debtors }\end{array}$ \\
\hline $\begin{array}{l}\text { Request the realization of } \\
\text { assets, a repayment plan, or } \\
\text { a combination of both }\end{array}$ & rec. 75 & $\begin{array}{l}\text { Structural option - results in very } \\
\text { different procedures, more or less } \\
\text { favorable to debtors and creditors }\end{array}$ \\
\hline $\begin{array}{l}\text { Set different periods for } \\
\text { discharge for different } \\
\text { procedures }\end{array}$ & rec. 75 & $\begin{array}{l}\text { Depends on the periods set for each } \\
\text { procedure. }\end{array}$ \\
\hline $\begin{array}{l}\text { Set an earlier time than the } \\
\text { confirmation of the } \\
\text { repayment plan for the } \\
\text { calculation of the discharge } \\
\text { period }\end{array}$ & rec. 75 & More favorable to debtors \\
\hline $\begin{array}{l}\text { Establish that the concept of } \\
\text { "opening of procedure" } \\
\text { does not include preliminary } \\
\text { measures }\end{array}$ & rec. 76 & Less favorable to debtors \\
\hline
\end{tabular}




\begin{tabular}{|c|c|c|}
\hline Issue & Article/ recital & Effect of option \\
\hline $\begin{array}{l}\text { Allow the insolvency estate } \\
\text { to be formed without a } \\
\text { formal decision }\end{array}$ & rec. 76 & Reduced complexity \\
\hline $\begin{array}{l}\text { Separate the request for } \\
\text { discharge from the } \\
\text { realization of assets in a } \\
\text { liquidation procedure }\end{array}$ & rec. 77 & $\begin{array}{l}\text { Reduced complexity; more favorable to } \\
\text { debtors }\end{array}$ \\
\hline $\begin{array}{l}\text { Establish rules on the } \\
\text { burden of proof regarding } \\
\text { discharge }\end{array}$ & rec. 77 ; rec. 78 & $\begin{array}{l}\text { Improve or worsen the position of } \\
\text { debtors }\end{array}$ \\
\hline $\begin{array}{l}\text { Extend the discharge } \\
\text { provisions to natural } \\
\text { persons who are not } \\
\text { entrepreneurs }\end{array}$ & art. 1 & Increased scope \\
\hline $\begin{array}{l}\text { Require that the economic } \\
\text { activity of the debtor has } \\
\text { ceased in order to access a } \\
\text { discharge procedure }\end{array}$ & art. 20.1 & Connection with national law \\
\hline $\begin{array}{l}\text { Allow the debtor to continue } \\
\text { the activity. In that case, } \\
\text { establish that a new } \\
\text { insolvency procedure can be } \\
\text { opened for that debtor }\end{array}$ & rec. 84 & Connection with national law \\
\hline $\begin{array}{l}\text { Maintain or introduce } \\
\text { provisions allowing judicial } \\
\text { or administrative authorities } \\
\text { to verify that the debtor has } \\
\text { fulfilled its obligations to get } \\
\text { a discharge }\end{array}$ & art. 21.1 ; rec. 82 & $\begin{array}{l}\text { Increased cost and complexity; curb } \\
\text { abuse }\end{array}$ \\
\hline $\begin{array}{l}\text { Exclude discharge when the } \\
\text { debtor has not complied } \\
\text { with certain obligations }\end{array}$ & rec. 79 & Increased complexity; curb abuse \\
\hline $\begin{array}{l}\text { Provide that the discharge } \\
\text { does not stop the insolvency } \\
\text { procedure }\end{array}$ & art. 21.2 & Increased functionality \\
\hline $\begin{array}{l}\text { Maintain or introduce } \\
\text { provisions denying or } \\
\text { restricting access to } \\
\text { discharge, or revoking } \\
\text { discharge }\end{array}$ & $\begin{array}{l}\text { art. } 23.1 ; 23.2 ; 23.3 \text {; rec. } \\
80\end{array}$ & $\begin{array}{l}\text { Less favorable treatment for debtors; } \\
\text { curb abuse }\end{array}$ \\
\hline
\end{tabular}




\begin{tabular}{|c|c|c|}
\hline Issue & Article/ recital & Effect of option \\
\hline $\begin{array}{l}\text { Provide for longer discharge } \\
\text { or disqualification periods in } \\
\text { some cases }\end{array}$ & art. $23.1 ; 23.2 ; 23.3$ & $\begin{array}{l}\text { Less favorable treatment for debtors; } \\
\text { curb abuse }\end{array}$ \\
\hline $\begin{array}{l}\text { Request the debtor to } \\
\text { submit a new application for } \\
\text { a new license after } \\
\text { disqualification }\end{array}$ & rec. 83 & Less favorable treatment for debtors \\
\hline $\begin{array}{l}\text { Exclude some debts from } \\
\text { discharge }\end{array}$ & art. 23.4 ; rec. 81 & $\begin{array}{l}\text { Less favorable treatment for debtors; } \\
\text { special protection of special claims }\end{array}$ \\
\hline $\begin{array}{l}\text { Provide for the adjustment } \\
\text { of repayment obligations } \\
\text { where there are significant } \\
\text { changes in the financial } \\
\text { situation of the debtor }\end{array}$ & rec. 74 & $\begin{array}{l}\text { Readjust the balance between creditors } \\
\text { and debtors; increased complexity and } \\
\text { functionality }\end{array}$ \\
\hline $\begin{array}{l}\text { Require that the repayment } \\
\text { plan is supported by a } \\
\text { majority of creditors }\end{array}$ & rec. 74 & $\begin{array}{l}\text { Increased creditor protection; less } \\
\text { favorable treatment of debtors }\end{array}$ \\
\hline $\begin{array}{l}\text { Allow debtors to start a new } \\
\text { activity during the } \\
\text { implementation of the } \\
\text { repayment plan }\end{array}$ & rec. 74 & Connection with national law \\
\hline $\begin{array}{l}\text { Provide for longer or } \\
\text { indefinite disqualification } \\
\text { periods in certain cases }\end{array}$ & art. 23.5 & $\begin{array}{l}\text { Less favorable treatment for debtors; } \\
\text { curb abuse }\end{array}$ \\
\hline $\begin{array}{l}\text { Separate professional and } \\
\text { personal debts, in } \\
\text { coordinated procedures }\end{array}$ & art. 24.2 ; rec. 84 & Connection with national law \\
\hline \multicolumn{3}{|l|}{ Institutional framework } \\
\hline $\begin{array}{l}\text { Establish training and } \\
\text { experience as a prerequisite } \\
\text { for judicial and } \\
\text { administrative authorities, } \\
\text { or allow to acquire training } \\
\text { and experience in the } \\
\text { exercise of their functions or } \\
\text { other relevant duties }\end{array}$ & rec. 85 & Alternative models for qualification \\
\hline $\begin{array}{l}\text { Create specialized courts or } \\
\text { chambers; appoint } \\
\text { specialized judges; or }\end{array}$ & rec. 86 & Alternative models for specialization \\
\hline
\end{tabular}




\begin{tabular}{|c|c|c|}
\hline Issue & Article/ recital & Effect of option \\
\hline $\begin{array}{l}\text { concentrate jurisdiction in a } \\
\text { limited number of courts or } \\
\text { administrative authorities }\end{array}$ & & \\
\hline $\begin{array}{l}\text { Prioritize insolvency cases } \\
\text { over other cases }\end{array}$ & rec. 86 & Increased functionality \\
\hline $\begin{array}{l}\text { Allow practitioners to } \\
\text { acquire suitable training, } \\
\text { qualifications and expertise } \\
\text { while practicing their } \\
\text { profession }\end{array}$ & rec. 87 & Alternative model for qualification \\
\hline $\begin{array}{l}\text { Establish that training of IPs } \\
\text { is provided by the state or } \\
\text { by professional associations } \\
\text { or other bodies }\end{array}$ & rec. 87 & Public or private models of training \\
\hline $\begin{array}{l}\text { Indicate who selects the } \\
\text { insolvency practitioner (e.g. } \\
\text { a debtor, creditor, creditor's } \\
\text { committee); and if it needs } \\
\text { to be approved by a judicial } \\
\text { or administrative authority. }\end{array}$ & rec. 88 & Alternative selection models \\
\hline $\begin{array}{l}\text { Indicate means of objection } \\
\text { to the selection of } \\
\text { insolvency practitioner, or } \\
\text { means to request the } \\
\text { replacement of the } \\
\text { insolvency practitioner }\end{array}$ & rec. 88 & Increased protection of parties \\
\hline $\begin{array}{l}\text { Provide that IPs are selected } \\
\text { from list or pools pre- } \\
\text { approved by a judicial or } \\
\text { administrative authority }\end{array}$ & rec. 88 & $\begin{array}{l}\text { Selection model with increased } \\
\text { reliability }\end{array}$ \\
\hline $\begin{array}{l}\text { Establish random selection } \\
\text { of IPs }\end{array}$ & rec. 88 & $\begin{array}{l}\text { Selection model to prevent integrity } \\
\text { issues; reduction of suitability of IPs. }\end{array}$ \\
\hline $\begin{array}{l}\text { Set up a special authority to } \\
\text { supervise IPs }\end{array}$ & rec. 89 & Increased supervision \\
\hline $\begin{array}{l}\text { Create new professions or } \\
\text { qualifications for IPs }\end{array}$ & rec. 89 & $\begin{array}{l}\text { Increased qualification; reduced } \\
\text { eligibility }\end{array}$ \\
\hline $\begin{array}{l}\text { Extend the provisions on the } \\
\text { training and supervision of }\end{array}$ & rec. 89 & $\begin{array}{l}\text { Increased qualification; reduced } \\
\text { eligibility }\end{array}$ \\
\hline
\end{tabular}




\begin{tabular}{|c|c|c|}
\hline Issue & Article/ recital & Effect of option \\
\hline \multicolumn{3}{|l|}{$\begin{array}{l}\text { insolvency practitioners to } \\
\text { other practitioners }\end{array}$} \\
\hline $\begin{array}{l}\text { Prioritize disputes over IPs } \\
\text { remuneration over other } \\
\text { disputes }\end{array}$ & rec. 89 & Unclear foundation \\
\hline $\begin{array}{l}\text { Encourage the adoption of } \\
\text { codes of conduct for } \\
\text { insolvency practitioners }\end{array}$ & art. 27.3 & Increased integrity \\
\hline $\begin{array}{l}\text { Establish mandatory use of } \\
\text { electronic systems }\end{array}$ & rec. 91 & Reduced cost; risk of barrier to access \\
\hline $\begin{array}{l}\text { Allow or request the use of } \\
\text { electronic means of } \\
\text { communication for more } \\
\text { cases than those included in } \\
\text { the Directive }\end{array}$ & art. 28 & Reduced cost; risk of barrier to access \\
\hline $\begin{array}{l}\text { Provide that notifications } \\
\text { can only be performed } \\
\text { electronically if the creditor } \\
\text { has previously consented to } \\
\text { it }\end{array}$ & rec. 90 & Increased protection for creditors \\
\hline \multicolumn{3}{|l|}{ Data collection } \\
\hline $\begin{array}{l}\text { Collect the optional data } \\
\text { included in the Directive }\end{array}$ & art. 29.3 & More coverage; higher cost \\
\hline $\begin{array}{l}\text { Use samples to collect } \\
\text { statistical data on } \\
\text { restructuring and insolvency }\end{array}$ & art. 29.5 & Less cost; less reliability \\
\hline $\begin{array}{l}\text { Include a breakdown of } \\
\text { procedures concluded } \\
\text { before confirmation }\end{array}$ & rec. 92 & More coverage; higher cost \\
\hline
\end{tabular}




\section{REFERENCES}

Arias Varona F.J., Niemi J., Hupli T., 2020, "Discharge and entrepreneurship in the preventive restructuring directive", Int. Insolv. Rev.; 29, 8-31.

Ballerini, G., 2020, “The priorities dilemma in the EU preventive restructuring directive: Absolute or relative priority rule?" Int. Insolvency Rev. 20 November 2020; https://doi.org/10.1002/iir.1399

Balp, G., 2019, "Early Warning Tools at the Crossroads of Insolvency Law and Company Law", Global Jurist Vol. 19; Issue 2, 22 Jan 2019.

Bergthaler. W., and Garrido, J., 2019, Corporate Insolvency and Debt Enforcement in the EU, Note 6, Background Notes for IMF SDN 19/07, 70-73.

Bhatia, A. V., Mitra, S., Weber, A., Aiyar, S., Antoun de Almeida, L., Cuervo, C., Oliveira Santos, A., Gudmundsson, T., 2019, A Capital Market Union for Europe, IMF SDN $19 / 07$.

Bricongne, J.-C., Demertzis, M., Pontuch, P., and Turrini, A., 2016, Macroeconomic Relevance of Insolvency Frameworks in a High-debt Context: An EU Perspective, EC, European Economy Discussion Paper 032.

Cahir, B., and Quinn, M., 2020, Procedural aspects, Insol Europe Guidance Note, London.

Carpus Carcea, M., Ciriaci, D., Cuerpo, C., Lorenzani, D., and Pontuch, P., 2015, The Economic Impact of Rescue and Recovery Frameworks in the EU, EC, European Economy Discussion Paper 004.

de Weijs, R.J., and Baltjes, M., 2018, “Opening the Door for the Opportunistic Use of Interim Financing: A Critical Assessment of the EU Draft Directive on Preventive Restructuring Frameworks", Int. Insolv. Rev., Vol. 27: 223-254.

de Weijs R.J., Jonkers A.L. and Malakotipour M., 2019, 'The Imminent Distortion of European Insolvency Law: How the European Union Erodes the Basic Fabric of Private Law by Allowing 'Relative Priority' (RPR)', Centre for the Study of European Contract Law Working Paper Series No. 2019-05.

de Weijs R, J., Jonkers A, Malakotipour M., 2019b, "A reply to Professor Madaus 'The new European Relative Priority from the Preventive Restructuring Directive-The end of European Insolvency Law?”, 15 March 2019. https://corporatefinancelab.org

Ehmke D.C., Gant J.L.L., Boon G., Langkjaer L., and Ghio E. 2019, “The European Union preventive restructuring framework: A hole in one?” Int. Insolv. Rev. 28, 1-26.

Eidenmüller, H., 2017, "Contracting for a European Insolvency Regime”, Eur Bus Org Law Rev $18,273-304$. 
Eidenmüller, H., 2019, "The Rise and Fall of Regulatory Competition in Corporate Insolvency Law in the European Union", Eur. Bus. Org. Law Rev. 20, 547-566.

European Commission (EC), 2014, Impact Assessment accompanying the Commission Recommendation on a New Approach to Business Failure and Insolvency, SWD (2014) 61 final.

EC, 2016, Impact Assessment accompanying the document "Proposal for a Directive of the European Parliament and the Council on preventive restructuring frameworks, second chance and measures to increase the efficiency of restructuring, insolvency and discharge procedures and amending Directive 2012/30/EU, \{COM (2016) 723 final $\}.$

Garrido, J. M., 2012, Out-of-court Debt Restructuring, A World Bank Study, Washington DC.

Garrido, J. M. (dir.), Bergthaler, W., DeLong, C., Johnson, J., Rasekh, A., Rosha, A., and Stetsenko, N., 2019, "The Use of Data in Assessing and Designing Insolvency Systems", IMF WP 19/27, https://www.imf.org/en/Publications/WP/Issues/2019/02/04/The-Use-ofData-in-Assessing-and-Designing-Insolvency-Systems-46549

Gassner, G., and Wabl, G., 2019, “ The new EU Directive on restructuring and insolvency and its implications for Austria", Insolvency and Restructuring International Vol 13 No 2, 5.

JCOERE Consortium, 2019, Report 1: Identifying substantive and procedural rules in preventive restructuring frameworks including the Preventive Restructuring Directive which may be incompatible with judicial co-operation obligations, Cork: JCOERE Project, University College Cork. Available at https://www.ucc.ie/en/jcoere/research/report1/

Liu, Y., Garrido, J., and DeLong, C., 2020, Private Debt Resolution in the Wake of the Pandemic, Special Series on COVID-19, International Monetary Fund. https://www.imf.org/ /media/Files/Publications/covid19-special-notes/en-special-serieson-covid-19-private-debt-resolution-measures-in-the-wake-of-the-pandemic.ashx

McCarthy, J. A., 2020, "Class Apart: The Relevance of the EU Preventive Restructuring Directive for Small and Medium Enterprises". Eur. Bus. Org. Law Rev.

McCormack, G., 2017, “Corporate Restructuring Law - A second chance for Europe?”, European Law Review, 42(4), 532-561.

Richter, T., and Thery, A., 2020, Claims, Classes, Voting, Confirmation and the Cross-Class Cram-Down, Insol Europe Guidance Note, London.

Rotaru, V., 2019, The Restructuring Directive: a functional law and economics analysis from a French law perspective, Droit \& Croissance / Rules for Growth Institute, Paris, France.

Schuijling, B., 2020, Stay of individual enforcement actions, Insol Europe Guidance Note, London. 
Seymour, J. M. and Schwarcz, S. L., 2021, "Corporate Restructuring under Relative and Absolute Priority Default Rules: A Comparative Assessment", Duke Law School Public Law \& Legal Theory Series No. 2019-84; U. ILL. L. REV., Forthcoming, Vol. 2021, No. 1 .

Skauradszun, D., and Nijnens, W., 2019, "Brussels Ia or EIR Recast? The Allocation of Preventive Restructuring Frameworks", International Corporate Rescue, Vol. 16, Issue 4, 193.

Stanghellini, L., Mokal, R., Paulus, C., and Tirado, I., 2018, Best Practices in European Restructuring: Contractualised Distress Resolution in the Shadow of the Law, Wolters Kluwer.

Tollenaar, N., 2017, “The European Commission's Proposal for a Directive on Preventive Restructuring Proceedings", 30 Insolvency Intelligence, 65.

Tollenaar, N., 2019, Pre-Insolvency Proceedings: A Normative Foundation and Framework, Oxford University Press.

Vermeille, S., 2018, Perverse effects of the absolute rule of confidentiality applicable to French amicable settlement procedures serving as preventive restructuring frameworks, Droit et croissance/ Rules for Growth, Paris.

Vermeille, S., and Rotaru, V., 2019, La directive Restructuration: un texte sans socle intellectuel cohérent, mais une opportunité unique pour la France, Droit et croissance/ Rules for Growth, Paris.

Zhang, D., 2019, "Preventive Restructuring Frameworks: A Possible Solution for Financially Distressed Multinational Corporate Groups in the EU”, Eur. Bus. Org. Law Rev. 20, 285318. 